OPEN ACCESS

Edited by:

Mar Pérez-Fortes,

Delft University of Technology,

Netherlands

Reviewed by:

Enrico Catizzone,

ENEA-Centro Ricerche Trisaia, Italy Yusuf Bicer,

Hamad bin Khalifa University, Qatar

*Correspondence:

Peter Styring

p.styring@sheffield.ac.uk

Specialty section: This article was submitted to Process and Energy Systems Engineering,

a section of the journal Frontiers in Energy Research

Received: 02 February 2021

Accepted: 06 May 2021

Published: 28 May 2021

Citation:

Styring P, Dowson GRM and Tozer 10 (2021) Synthetic Fuels Based on Dimethyl Ether as a Future Non-Fossil Fuel for Road Transport From

Sustainable Feedstocks. Front. Energy Res. 9:663331. doi: 10.3389/fenrg.2021.663331

\section{Synthetic Fuels Based on Dimethyl Ether as a Future Non-Fossil Fuel for Road Transport From Sustainable Feedstocks}

\author{
Peter Styring *, George R. M. Dowson and Isabel O. Tozer \\ UK Centre for Carbon Dioxide Utilisation, Chemical \& Biological Engineering, Sir Robert Hadfield Building, The University of \\ Sheffield, Sheffield, United Kingdom
}

In this review we consider the important future of the synthetic fuel, dimethyl ether (DME). We compare DME to two alternatives [oxymethylene ether $\left(\mathrm{OME}_{\mathrm{x}}\right)$ and synthetic diesel through Fischer-Tropsch (FT) reactions]. Finally, we explore a range of methodologies and processes for the synthesis of DME.

$\mathrm{DME}$ is an alternative diesel fuel for use in compression ignition $(\mathrm{Cl})$ engines and may be produced from a range of waste feedstocks, thereby avoiding new fossil carbon from entering the supply chain. DME is characterised by low $\mathrm{CO}_{2}$, low $\mathrm{NOx}$ and low particulate matter (PM) emissions. Its high cetane number means it can be used in $\mathrm{Cl}$ engines with minimal modifications. The key to creating a circular fuels economy is integrating multiple waste streams into an economically and environmentally sustainable supply chain. Therefore, we also consider the availability and nature of low-carbon fuels and hydrogen production. Reliable carbon dioxide sources are also essential if $\mathrm{CO}_{2}$ utilisation processes are to become commercially viable. The location of DME plants will depend on the local ecosystems and ideally should be co-located on or near waste emitters and low-carbon energy sources. Alternative liquid fuels are considered interesting in the medium term, while renewable electricity and hydrogen are considered as reliable long-term solutions for the future transport sector. DME may be considered as a circular hydrogen carrier which will also be able to store energy for use at times of low renewable power generation.

The chemistry of the individual steps within the supply chain is generally well known and usually relies on the use of cheap and Earth-abundant metal catalysts. The thermodynamics of these processes are also well-characterised. So overcoming the challenge now relies on the expertise of chemical engineers to put the fundamentals into commercial practice. It is important that a whole systems approach is adopted as interventions can have detrimental unintended consequences unless close monitoring is applied. This review shows that while DME production has been achieved and shows great promise, there is considerable effort needed if we are to reach true net zero emissions in the transport sector, particularly long-haul road use, in the require timescales.

Keywords: dimethyl ether, diesel, net zero carbon, de-fossilise, synthetic fuel, e-fuels 


\section{INTRODUCTION}

The drive towards 'net zero' policies in the United Kingdom, and indeed globally, has led to a re-evaluation of energy policies. While the obvious sectors needed to maximise emissions reductions are electricity and heating, a considerable quantity of energy is consumed by the transportation sector, including road, rail, aviation and maritime. The urgent need to decarbonise, or more correctly, de-fossilise, the transport sector is a huge challenge. Internal combustion engines (ICEs) have been developed and optimised over many decades and represent the most abundant form of mobility powertrains. While there has been a governmental drive in the United Kingdom to replace ICEs with electric vehicles (EVs), a recent report by the Royal Society (Royal Society, 2019) has also considered policies surrounding a migration to synthetic transport fuels. The reason is partly because a transition to an EV infrastructure would require a complete overhaul of the electricity supply chain and economics. While plug-in battery electric vehicles (BEVs) provide zero tailpipe emissions, the energy required to power them needs to be generated elsewhere.

In the current electrical energy grid mix the amount of renewable power available is dependent on many factors including weather and demand. In the United Kingdom, low carbon energy (including nuclear) accounts for 55\% of the electricity generated on average across a year (2019 figures, UK Department for Business, Energy and Industrial Strategy, 2020). This means that nearly half of the electricity remains fossilderived and so the emissions for BEVs are deferred to the power generator. Therefore, BEVs cannot truly be considered as zeroemissions vehicles if a complete life cycle is carried out to include deferred electricity generation within the system boundaries. Furthermore, it is also necessary to include the battery manufacture and disposal of end-of-life units in the environmental analyses (Wang and Yu, 2021).

In a transition to net zero emissions, due to the economic inertia of the existing supply infrastructure and logistics, it is wellworth considering a graduated transition rather than attempting a step change. For example, in compression ignition vehicles (CIVs) such as diesel, it is not the engine that is the problem but the fuels. Rather than significantly redesigning the engine, can we instead redesign the fuels? In the case of diesel replacement, one fuel that is attracting considerable attention is dimethyl ether $(\mathrm{DME})$ and the family of oxymethylene ethers $\left(\mathrm{OME}_{\mathrm{x}}\right)$ where $\mathrm{DME}$ is equivalent to $\mathrm{OME}_{0}$ and $\mathrm{x}$ is the number of additional oxymethylene units $\left(-\mathrm{CH}_{2}-\mathrm{O}-\right)$ within the molecule. Alternative liquid fuels are interesting in the medium term, while renewable electricity and hydrogen are considered as reliable long-term solutions for the future transport sector. DME may be considered as a circular hydrogen carrier which will also be able to store energy for use at times of low renewable power generation.

Work by Willems at Ford has shown that in engine tests, not only is there zero SOx emissions associated with DME fuels (because the fuel is not fossil-derived) but due to the reduced carbon content in the molecules compared to diesel, $\mathrm{CO}_{2}$ emissions can be as low as $3 \mathrm{~g} / \mathrm{km}$, compared to EU 2020 standard diesel car emissions of $95 \mathrm{~g} / \mathrm{km}$ (European Council directive, 443/2009; European Council directive, 443/2009). Furthermore, as less air is needed and the flame temperature is lower there are practically zero NOx emissions, and because there are no $\mathrm{C}-\mathrm{C}$ bonds in the ether molecules particulate matter (PM or soot) is also practically zero (Lee et al., 2016). Therefore, compared to current electricity grid mixes and emissions in power generation for EVs, the full scope life cycle emissions for DME-CIVs could be considerably lower.

We recently published a review on the synthesis of oxygenated transport fuels from carbon dioxide (Styring and Dowson, 2021), including DME which prompted us to consider expanding the range of feedstocks to include other materials considered to be waste. Unilever have recently announced their ambitions to remove fossil-based carbon materials from their supply chain by using waste materials described by Unilever as a 'Carbon Rainbow' (Unilever, 2020). This includes 'Purple' carbon $\left(\mathrm{CO}_{2}\right)$, 'Green' carbons (bio-based), 'Blue' carbons (marine based) and 'Grey' carbons (general waste including plastics). Using these principles, we present an up-to-date analysis of routes to DME/ $\mathrm{OME}_{\mathrm{x}}$ using waste feedstocks to eliminate fossil-carbon from the fuels supply chain.

This paper aims to show that DME is a useful mobility fuel that can be used as a diesel drop-in fuel that requires only slight modifications to existing combustion engines. This will allow low-emissions fuels to be used in legacy combustion engines while the industry and society transitions to electric vehicles in the mid- to long-term. Comparisons are made to FT and OME ethers which may also be used as drop-in fuels. We consider the technology available, and the feedstocks needed to assure a just and economically viable move to synthetic fuels.

\section{CARBON NEUTRAL FUELLING OPTIONS}

Carbon neutrality, or the aim to reach a net zero state, refers to the balance between reducing carbon dioxide emissions as far as possible and removing the remaining of carbon dioxide from the atmosphere. The European Union has committed to climate neutrality by 2050 which includes the goal of being a society with net-zero greenhouse gases. This commitment is also in line with the legally binding Paris agreement as signed by 190 parties (United Nations, 2015).

Transport is fundamental to modern living and is a key stimulator for societal improvement and economic growth. However, the negative externalities surrounding the emissions caused by transport indicate that it is a key sector for improvement to reach a net zero state.

In order to create carbon neutral transport, a multitude of options need to be considered for the many different forms of transport. The breakdown of global $\mathrm{CO}_{2}$ emissions per transport division can be seen in Figure 1 (Our World in Data, 2020).

Some transport sectors have already been optimised to reduce $\mathrm{CO}_{2}$ emissions. For example, the majority of passenger rail links across the globe have been, or are in the process of being, electrified (IEA, 2019). Thus, rail emissions only contribute to $1 \%$ of the global $\mathrm{CO}_{2}$ emissions from transport (Our World in Data, 2020). 


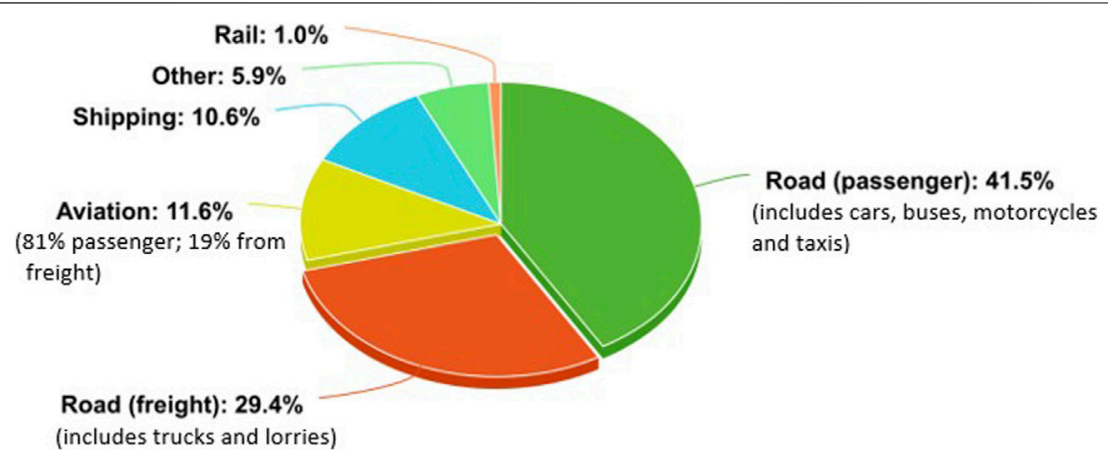

(includes trucks and lorries)

FIGURE 1 | Breakdown of global $\mathrm{CO}_{2}$ emissions per transport division.

When looking at electrification and carbon neutrality, again it is important to recognise that in order to be truly carbon neutral the electricity source must also be made in a carbon sustainable manner. Carbon sustainable electricity sources include renewables such as energy retrieved from solar and wind farms, or energy options form sources such as nuclear which has a negligible direct production of $\mathrm{CO}_{2}$ (IEA, 2020a). Concentrating on road transport which dominates an estimated $71 \%$ of the transport $\mathrm{CO}_{2}$ emissions, there are two key sectors, passenger and freight. In order to reach net zero, carbon neutral fuel options need to be considered and implemented in both these sectors. However, the same methods can not necessarily be used for each sector, due to their different working requirements.

The main driving force in United Kingdom passenger transport is the electrification of the vehicle fleet, with the United Kingdom government promising to ban the sale of new combustion-engine vehicles by 2030 (Johnson, 2020). This United Kingdom policy however does not cover freight and heavy goods vehicles (HGVs) as there are many issues surrounding their electrification. The barriers that would need to be overcome by an advance in battery technology in order to electrify the HGV fleet include the long charging time and limited driving range of existing batteries. An increase in the size of the battery to solve these problems, rather than an increase in efficiency, would lead to the weight and size of the battery being too much to make it a viable and cost-effective option (Sia Partners, 2016). Current research on using BEVs to support large heavy goods vehicles over 15 tonnes, shows low feasibility for a conventional vehicle configuration due to their increased loads and the longer trip distances required. The possibility of BEVs supporting lighter medium goods vehicles (3.5-7.5 tonnes) and smaller heavy goods vehicles (7.5-15 tonnes) would require multiple charging events a day which would decrease sector efficiency and require a massive infrastructure change (Forrest et al., 2020). While fast charging of large battery-powered goods vehicles may be possible in principle, this will require enormous electrical power availability at major recharging stations (such as motorway services), especially when multiple heavy goods vehicles will need to be charged simultaneously. We have calculated that to allow fast charging ( $1 \mathrm{~h}$ charge) of upcoming battery goods vehicles such as the Freightliner eCascadia or the
Tesla Semi (long range), power supplies between $0.56-0.68$ and $1.12-1.36$ megawatts per vehicle respectively would need to be made available at recharging stations. This is based on battery sizes of 500 and $1,000 \mathrm{kWh}$ in these vehicles and a $64-88 \%$ charging efficiency (Apostolaki-Isofidou et al., 2017), which may be lower when fast charging such large batteries (Michaelides, 2020). Note that a single full charge of the larger battery, enough for a truck to drive for a full 9-hour day (approximately 500 miles), requires around a third of the electricity the average United Kingdom household will use in a year (O'Mahoney, 2020). Indeed, the scale of challenges facing electrification of larger heavy goods vehicles by using batteries has promoted the alternative concept of electrification by use of overhead cables and cabin-mounted pantographs in the United Kingdom and abroad (Ainalis et al., 2020), eliminating much of the battery weight.

Other on-board storage strategies include hydrogen fuel cell technology. However, there is still a lack of the technology and supply infrastructure that would be required to allow for widespread adoption of this technology. Depending on the production method used, the cost of producing hydrogen is up to seven times more than that of petrol and diesel (Abbasi and Abbasi, 2011). Furthermore, introducing hydrogen fuel cell technology would also require a mass investment in and restructure of fuelling infrastructure due to the necessity for new fuelling stations and pipelines (Popov et al., 2018).

As alternative on-board power sources (such as hydrogen fuel cell technology) require entirely new fleets of vehicles together with significant and very costly infrastructure changes, there is a gap in the market for synthetic fuels or biofuels, particularly those which can be fed into the existing supply infrastructure. Furthermore, synthetic fuels such as DME are circular hydrogen carriers and utilise hydrogen as a method of storing energy in a vector form that can be transported and stored with more ease and safety than using hydrogen as the singular fuel source (Catizzone et al., 2021).

Biofuels are fossil replacement transport fuels made directly from biomass, instead of from fossil-based carbon sources. The most widely used biofuels for transport are bioethanol and biodiesel. Bioethanol can be produced from first generation feedstock e.g. sugarcane as well as second generation feedstock such as lignocellulose. The complexity of the process increases 


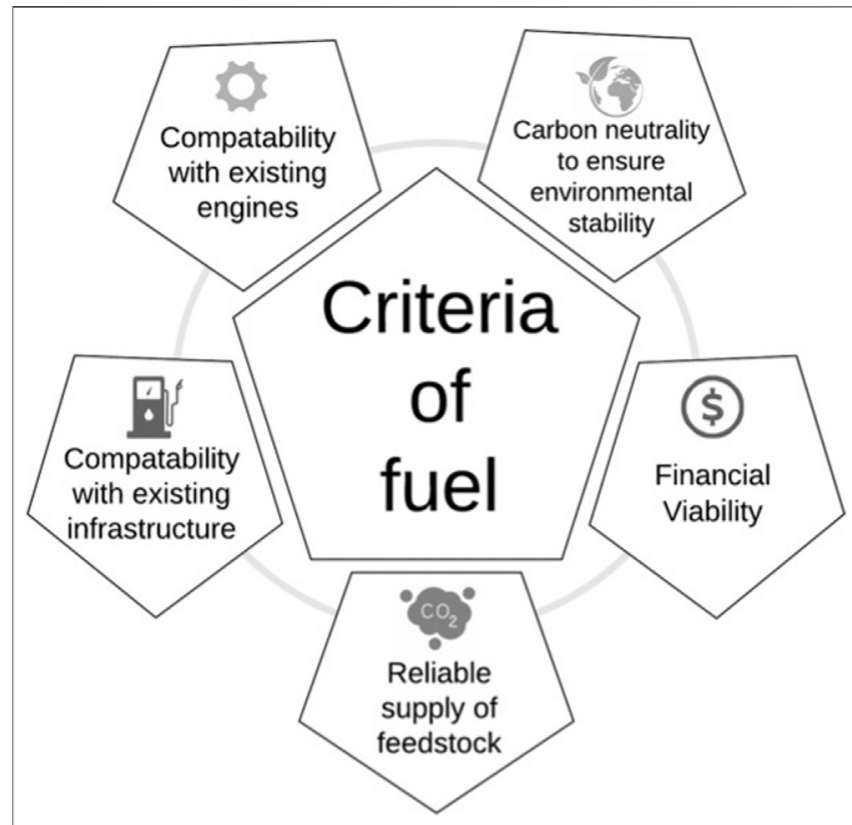

FIGURE 2 | The criteria of fuel.

as you go from 1 st $\rightarrow$ 2nd $\rightarrow$ 3rd generation, however the movement away from 1st generation feedstock avoids a key barrier for the production of biofuels, namely the food vs fuel argument (Prasad and Ingle, 2019). Biodiesel manufactured mainly in the EU is produced by the transesterification and esterification of vegetable oils or animal fats with alcohols such as methanol (Brito Cruz et al., 2014). Although regarded as one of the most viable options for the reduction of $\mathrm{CO}_{2}$ in transport, biofuels only acquired around a 3\% share of total global transport fuel demand in 2018 (IEA, 2020b) due to limitations such as raw material supply insufficiency, the low mitigation of $\mathrm{CO}_{2}$ and low-cost competitiveness (Oh et al., 2018). In order for biofuels to cope with the increasing demand for carbon neutral fuelling options, development in advanced biofuels using inedible biomass looks to be a promising solution.

It is clear that there is no single "silver bullet" solution to decarbonisation of existing transport modes, including long haul transport, aviation and maritime transport, that does not, in turn, have further issues in terms of either public or private financing, raw material availability or technology readiness. While conventional fossil diesel fuel may be eventually banned, starting with the elimination of new diesel passenger vehicles in the United Kingdom in 2030 (Johnson, 2020), engines that currently burn diesel and kerosene are still very likely to be used and needed much further into the future. Indeed, the legacy vehicles purchased before 2030 will still require fuels until they reach their end of life. While this could be fossil-based petrol and diesel, there is an opportunity to introduce alternative fossil-free fuels such as DME to accelerate the de-fossilisation of the passenger transport fleet while EVs become more established.

\section{CRITERIA OF THE FUEL}

For a synthetic liquid fuel to be the best option to move freight vehicles to a carbon neutral transport source, it needs to fulfil the 'fuel criteria'. This includes the environmental cost, referring primarily to whether it can be made sustainably in order to make it carbon neutral, but also other environmental factors (such as resource depletion, water use and generation of other pollutants) which must be considered in detailed life cycle assessment. It also refers to whether the fuel itself can be made in a financially viable manner so that the industry can continue to work profitably without continued reliance on substantial government subsidies. Additional criteria include the supply and scope of the new fuel and the reliability of supply. Compatibility with the existing global infrastructure and combustion engines is also essential. Finally, it would be advantageous if it were possible to mix the new fuel with existing fuels. This would allow immediate introduction of the new fuel and therefore an immediate transition towards carbon neutrality. This has the added advantage that it would either comply with existing legislation or fall within the scope of realistically foreseeable future legislation. These criteria are illustrated in Figure 2.

Synthetic liquid fuels in this setting work from the principle of defossilisation rather than decarbonisation. This is due to the fuel still being a carbon combustion source. The feedstock material being captured carbon dioxide which is utilised (CCU) or other sustainable carbon resource to synthesise the fuels (Global Alliance Powerfuels, 2020). Defossilisation acknowledges that it is not just carbon atoms being present in the atmosphere which cause dangerous climate change but rather the increase in the overall concentration of the carbon atoms. Thus, it is the carbon atoms derived from fossil sources that need to be prevented from reaching the atmosphere (ETIP PV, 2020). Although during the use phase of using synthetic liquid fuels carbon will be a factored emission in such forms as $\mathrm{CO}_{2}$ and lesser so carbon particulates within the life cycle of the fuel, the circular nature of $\mathrm{CO}_{2}$ being both the initial feedstock and final product in the forms of emissions, leads the fuel to have similar inclusive carbon emissions as carbon free fuels such as hydrogen and ammonia. This minimises the environmental concerns. Further environmental concerns coming from conventional fuels can also be diminished. This is because certain liquid synthetic fuels can reduce other emissions such as NOx, whereas carbon-free fuels currently being researched in a dual-fuel capacity show high NOx emissions and unburnt ammonia due to the fuel-bound nitrogen (Dimitriou and Javaid, 2020).

In order to maintain a carbon neutral fuel source, the carbon atoms that are taken away from the atmosphere in the form of the material feedstock need to be equal in number to the carbon atoms released when the fuel is burnt, with no additional fossil carbon used. Subsequently, the energy-intensive processes of synthesising the fuels need to be powered by renewable energy sources, such as wind, solar and hydro. Nuclear fuel, although not considered renewable, is a low-carbon source of energy suitable for clean electricity provision for the production of synthetic fuels. It should also be noted that recent research considered extracting uranium from seawater, making nuclear power a 
significantly more sustainable and egalitarian energy source (Parker et al., 2018). It has also been suggested that as there is growing demand for renewable energy sources and as the sources are not always constant, the use of excess-energy during low periods of demand can be used to produce synthetic fuels (Luo et al., 2015) rather than being "wasted" by curtailment. In this way the liquid fuels acts as an energy vector that can be stored using existing facilities and infrastructure. This could boost the financial value of the renewable energy source. To determine and demonstrate the true carbon neutrality of a fuel an environmental lifecycle assessment can be used (Zimmermann et al., 2020).

A viable synthetic fuel also needs to a financially sound investment. Here, the variables that contribute into the cost of the fuel are the feedstock materials, production costs and the fuelto-vehicle transport, otherwise known as the fuelling infrastructure. As previously mentioned, for a synthetic liquid fuel to be financially viable in comparison to other fuelling methods, one main component is that the fuel would be compatible with current pipelines, infrastructure and combustion engines (Willems, 2018).

To be financially viable, the synthesis route also needs to be cost-effective. This may differ depending on the country in which country the fuel is produced. For example, the cost of producing electricity in France is low due to the high use of low-cost nuclear energy sources (Nuclear Power in France | French Nuclear Energy - World-nuclear.org, 2020). If the low cost of nuclear electricity production could be exploited, it could be more realistic for France to use the energy intensive hydrolysis method of hydrogen production. The specific route for the generation of the fuel from sustainable carbon and how that carbon is acquired or captured will be compared in a later section.

Finally, to be the answer to the carbon neutral fuelling crisis, ideally the synthetic fuel would be compatible with current combustion engines as this would mean that current trucks and HGVs could be made carbon neutral by just changing the fuelling source instead of changing the engine or having to build a new fleet of HGVs entirely. This would give an enormous advantage because of the existing fuelling infrastructure. If this is the case, and the new fuel can be mixed with conventional fuels, this allows a gradual transition towards higher concentrations of the low carbon fuel whist the supply line is developed and ramped in scale sufficiently to replace the current supply demands. However, mixing of fuels and using different fuels in existing engines and within existing infrastructure may encounter legislation restrictions which may need to be changed in order to make a smooth and complete legal shift (European Council directive 2018/2001). this will depend on a variety of factors from the degree of blending and the nature of the new fuel to the intended use of the fuel.

\section{TYPE OF SYNTHETIC FUEL CONSIDERED}

For the reasons explained above we are interested in fuels that have a possibility of being "drop-in" compatible with diesel combustion engines (the most common in goods vehicles) and which would only require limited retrofitting of existing engines (such as replacing the fuel tank) rather than the development of a completely new engine. Accordingly, we have not focussed on hydrogen directly as a synthetic fuel, because an additional fuel cell or significant change to HGVs' internal combustion engines would be required.

The fuels that best meet most or all of these criteria are dimethyl ether (DME), oxymethylene ether $\left(\mathrm{OME}_{\mathrm{x}}\right)$ and potentially synthetic diesel through Fischer-Tropsch (FT) reactions. These are considered individually below.

\section{Dimethyl Ether}

DME is a liquefied gas that has been identified as a potential diesel fuel replacement. It has a chemical formula of $\mathrm{CH}_{3} \mathrm{OCH}_{3}$. Its structure is illustrated in Figure 3.

Using DME as a fuel significantly reduces NOx output in comparison to conventional diesel engines due to lower flame temperatures and more efficient combustion. Additionally, DME combustion produces far less particulate matter (Pélerin et al., 2020), which is a significant concern in major cities around the world. The lack of particulate matter is due to the absence of $\mathrm{C}-\mathrm{C}$ bonds in $\mathrm{DME}$, this results in the clean burning and the shorter ignition delay compared to diesel (Kajitani et al., 1997). Rather than C-C bonds, the abundance of $\mathrm{C}-\mathrm{O}$ bonds leads to a vast reduction in unburnt hydrocarbon fuel exhaust. This is because the extra presence of oxygen in the combustion leads to complete combustion and results in less carbon monoxide and unburnt carbon (soot) being produced. The additional oxygen in the molecular structure also reduces the amount of air required for the same energy output in the engine, which further reduces NOx generation. The particulate yields for DME are $0.013 \%$ compared to that of regular diesel $(0.026 \%)$ or biodiesel engines (0.51\%) (Sidhu et al., 2001).

The liquefied gas has a boiling point of $-25.05^{\circ} \mathrm{C}$. This, in combination with the differences in other physical properties, such as the viscosity and calorific value, means that some changes to a vehicle would be required to make DME a suitable replacement for diesel (Willems et al., 2020). In order to retrofit existing diesel HGVs either low level retrofitting (replacing the tank for on-board blending) or high-level retrofitting (low level plus the additional replacement of the injection system and air path modification) is required; these come at an estimated additional cost to consumers of $\approx 4 \mathrm{k} € /$ truck or $\approx 7 \mathrm{k} € /$ truck respectively (INERIS, 2020).

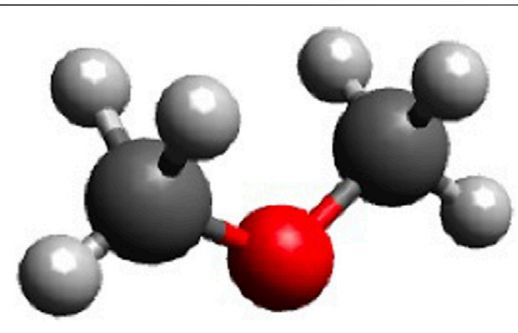

FIGURE 3 | The structure of DME (built in Avogadro, 2021). 
TABLE 1 |The comparison between the properties of DME, diesel and methanol can be seen in (Arcoumanis et al., 2008), (Worldwide Fuel Charter Committee, 2019), (Wang et al., 2020), (US deperatment of energy, 2021):

\begin{tabular}{|c|c|c|c|c|}
\hline Property (unit/condition) & Unit & Diesel & DME & Methanol \\
\hline Chemical structure & & $\begin{array}{c}\text { Av. } \mathrm{C}_{15} \mathrm{H}_{28} \\
\text { Range } \mathrm{C}_{12}-\mathrm{C}_{20}\end{array}$ & $\mathrm{CH}_{3}-\mathrm{O}-\mathrm{CH}_{3}$ & $\mathrm{CH}_{3} \mathrm{OH}$ \\
\hline Oxygen content & Mass $\%$ & 0 & 34.8 & 50 \\
\hline Final boiling point & ${ }^{\circ} \mathrm{C}$ & 365 & -25.05 & 64.7 \\
\hline Density at $15^{\circ} \mathrm{C}$ & $\mathrm{kg} / \mathrm{m}^{3}$ & $815-850$ & 667 & 797 \\
\hline Cetane number & & $>51$ & $>55$ & 5.0 \\
\hline Lower heating value & $\mathrm{MJ} / \mathrm{kg}$ & 43.8 & 27.6 & 22.7 \\
\hline Volume required for diesel equivalence & $\mathrm{m}^{3} / \mathrm{m}^{3}$ & 1 & 1.8 & 2.2 \\
\hline
\end{tabular}

As shown in Table 1, DME has a higher cetane number than diesel. This allows it to perform well as a fuel alternative since the low auto-ignition temperature in combination with the low boiling point means that the fuel, once injected into the system, vaporises almost instantly leading to reduced ignition delay and good cold-starting properties (Teng et al., 2001).

However, a consideration for fuel substitution is that due to the lower heating value (LHV) of DME in comparison with diesel, the equivalent fuel volume of DME to diesel is 1:1.8 L proficiently (McKone et al., 2015). Thus, larger fuel tanks are needed to fulfil the same distance requirements, and these fuel tanks must be designed to handle the gaseous fuel. This, along with other vehicle changes such as timing, air fuel mixture ratios and alternative lubrication methods encompass most of the modest modifications required to allow conventional diesel engines to run using DME.

However, while pure DME is not compatible with gasoline or petrol engines that use spark ignition, it can be used in a $30 \%$ DME/70\% liquified petroleum gas (LPG) ratio, potentially also allowing some non-diesel vehicles to run up to $30 \%$ cleaner in terms of $\mathrm{CO}_{2}$ emissions (IDA Fact Sheet No. 2, 2010).

Although a gas at room temperature, DME has a comparable vapour-pressure interaction to LPG which forms a liquid phase above $0.5 \mathrm{MPa}$ (5 bar). Therefore, DME has similar characteristics to LPG, which is widely transported (Verbeek and Van der Weide, 1997) and so would be compatible with existing transport infrastructure. Additionally, DME can be used as a carbon neutral feedstock for production of olefins using a zeolite catalyst. This provides an innovative mechanism for making carbon neutral polymers and other products that are usually derived from petrochemicals (Galanova et al., 2021).

The colourless DME gas has no negative health effects. Even at high vapour concentrations the human reaction is only that of a small narcotic response (Arcoumanis et al., 2008). Due to historical usage of DME as an aerosol propellent, the safety aspects of DME exposure have been evaluated extensively (McKone et al., 2015).

\section{Dimethyl Ether Efficiency}

The basic cycle of carbon-based greenhouses gases and other sustainable carbon sources to produce DME fuels follows $\mathrm{CO}_{2} /$ $\mathrm{CH}_{4}$ capture and storage from a variety of sources including, but not limited to, power, steel, cement and other industrial plants, landfill sites, waste to gas by anaerobic digestion and potentially air-captured $\mathrm{CO}_{2}$. The well-to-miles or well-to-wheel cost compares different fuelling solutions and their impact on climate change through greenhouse gas emissions (Semelsberger et al., 2006). DME has shown high well-to-wheel efficiency, demonstrated using a fleet of DME-fuelled Volvo vehicles operating on sustainable feedstocks (IDA Fact Sheet No. 2, 2010). Well-to-tank efficiencies have varying values from various sources as this is dependent on the designation of affecting variables. The higher values of well-to-tank efficiencies come with the assumption of total vehicle efficiency of $40 \%$, with the well-to-tank portion calculated at $27 \%$, whereas a well-to-wheel efficiency of $18 \%$ was calculated using conventional technology (Semelsberger et al., 2006). The efficiencies will also change depending on the source of the carbon dioxide.

'Well-to-miles' calculations show a $2 \%$ overall change when comparing air as a carbon dioxide source in comparison to biogas in passenger vehicles (Hänggi et al., 2019). Although the well-tomiles efficiency is lower than that in conventional diesel and petrol engines due to the high well-to-tank efficiency of these established processes, DME fuel has an equivalent or higher efficiency than all other alternative transport fuels in the study (Semelsberger et al., 2006). If DME becomes a conventional feedstock, the well-to-tank efficiency would increase as technology is developed and perfected.

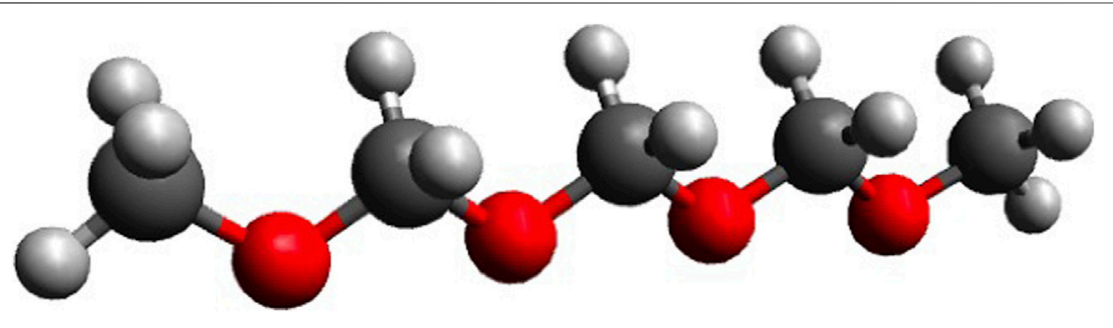

FIGURE 4 | The structure of $\mathrm{OME}_{3}$ (built in Avogadro, 2021). 
TABLE 2 | Comparison of $\mathrm{OME}_{\mathrm{x}}$ and diesel properties.

\begin{tabular}{|c|c|c|c|c|c|c|c|}
\hline Property (unit/condition) & Unit & Diesel & $\mathrm{OME}_{1}$ & $\mathrm{OME}_{2}$ & $\mathrm{OME}_{3}$ & $\mathrm{OME}_{4}$ & $\mathrm{OME}_{5}$ \\
\hline Chemical structure & & $\begin{array}{c}\text { Av. } \mathrm{C}_{15} \mathrm{H}_{28} \\
\text { Range } \mathrm{C}_{12}-\mathrm{C}_{20}\end{array}$ & $\mathrm{C}_{3} \mathrm{H}_{6} \mathrm{O}_{2}$ & $\mathrm{C}_{4} \mathrm{H}_{10} \mathrm{O}_{3}$ & $\mathrm{C}_{5} \mathrm{H}_{12} \mathrm{O}_{4}$ & $\mathrm{C}_{6} \mathrm{H}_{14} \mathrm{O}_{4}$ & $\mathrm{C}_{7} \mathrm{H}_{16} \mathrm{O}_{6}$ \\
\hline Oxygen content & Mass $\%$ & 0 & 42.1 & 45.2 & 47 & 48.1 & 48.9 \\
\hline Final boiling point & ${ }^{\circ} \mathrm{C}$ & 365 & 42 & 105 & 156 & 202 & 242 \\
\hline Density at $15^{\circ} \mathrm{C}$ & $\mathrm{kg} / \mathrm{m}^{3}$ & $815-850$ & 860 & 980 & 1,030 & 1,070 & 1,110 \\
\hline Cetane number & & $>51$ & 29 & 63 & 67 & 76 & 90 \\
\hline Lower heating value & $\mathrm{MJ} / \mathrm{kg}$ & 43.8 & 22.4 & 20.6 & 19.4 & 18.7 & 18.1 \\
\hline Volume required for diesel equivalence & $\mathrm{m}^{3} / \mathrm{m}^{3}$ & 1 & 1.77 & 1.75 & 1.7 & 1.7 & 1.7 \\
\hline
\end{tabular}

\section{Oxymethylene Ethers $\left(\mathrm{OME}_{\mathrm{x}} / \mathrm{OME}_{\mathrm{n}}\right)$}

$\mathrm{OME}_{\mathrm{x}}$ are related to DME with the chemical formula of $\mathrm{CH}_{3} \mathrm{O}$ $\left(\mathrm{CH}_{2} \mathrm{O}\right)_{\mathrm{x}}-\mathrm{CH}_{3}, \mathrm{x}=1-8$ (Ouda et al., 2018). $\mathrm{OME}_{\mathrm{x}}$ as DME derivatives have similar properties but a higher molecular mass and boiling points. An example of the chemical structure of an $\mathrm{OME}_{3}$ molecule is illustrated in (Figure 4).

The oligomer length of the OME has a significant effect on the physical properties of the fuel. However, due to the increased length and higher boiling point in comparison to DME, the fuel acts similarly to LPG but has physical, chemical and fuel-properties similar to conventional diesel (Deutsch et al., 2017). The similarities allow conventional diesel supply structures to be used without significant alterations (Oestreich et al., 2018). This allows OME to be a direct replacement for fossil fuels as an immediate "drop in" replacement (Deutz et al., 2018).

$\mathrm{OME}_{\mathrm{x}}$ also have no C-C bonds so are clean burning as discussed above in relation to DME. Similarly, precursors for soot such as $\mathrm{C}_{2} \mathrm{H}_{2}$ are inhibited in the combustion cycles (Sun et al., 2017). Another advantage of minimal particulate matter production is that there is a reduction in fouling in engine parts such as in the exhaust gas recirculation system (Härtl et al., 2017).

As the oligomer lengths affect the fuel properties, the compatibility and suitability of OMEx as a diesel replacement is dependent on oligomer length. Properties of different oligomer length OMEs and a comparison to diesel properties are shown in Table 2 (Worldwide Fuel Charter Committee, 2019), (Härtl, et al., 2017).

The operating efficiency of a modern diesel engine will decrease if the cetane number is not higher than 51 . Therefore, $\mathrm{OME}_{1}$ is not a viable candidate as a replacement for diesel fuels.

An increase in the length of the oligomer sees a decrease in the lower heating value. The lower heating value determines the rate of flow of fuel required into the engine needed for the defined output energy from the engine. If a fuel has a lower heating value a high volume of fuel is required to meet the same energy output. The increase in density with oligomer length does help combat this issue. The volume of fuel needed for fuel equivalence is $1.7 \mathrm{x}$ that of diesel $\mathrm{m}^{3} / \mathrm{m}^{3}$.

\section{Fischer-Trospch Diesel}

Fischer-Trospch (FT) diesel is produced from syngas condensation $\left(\mathrm{CO} / \mathrm{H}_{2}\right)$ and post-processing to create a synthetic fuel that has a similar long chain hydrocarbon structure to conventional diesel. However, the fuel properties can vary from batch to batch due to the changing of process temperatures, catalysts and feedstock quality (Alleman and McCormick, 2003) with variations that can be used to tailor the fuels to the end-users needs (Gill et al., 2011).

Although very similar to conventional diesel, FT diesel has virtually no sulfur or aromatic hydrocarbons (Abu-Jrai et al., 2006). Although this decreases emissions such as SOx, the sulphur and aromatic contents of conventional diesel provide it with natural lubricity, which is absent in FT diesel. However, this can be rectified by commercial additives (RodríguezFernández et al., 2019). The high cetane number of fuels that can be derived from the F-T process also show a high potential for reducing the NOx/PM trade-off seen in conventional diesel engines (Rounce et al., 2009).

\section{SYNTHESIS ROUTES}

\section{Fischer-Tropsch Diesel}

FT synthesis is classified into high temperature $\left(310-340^{\circ} \mathrm{C}\right)$ and low temperature $\left(210-260^{\circ} \mathrm{C}\right)$ reactions (Leckel, 2009). The low temperature and high temperature methods give different compositional outcomes. Low temperature provides a higher cetane number and paraffinic compounds more suitable as diesel fuels. High temperature FT is more suitable as a gasoline substitute. One draw-back to the low temperature product is the lower density than conventional diesel which may lead to a need to reconfigure the fuel injection strategy and hardware (Larsson and Denbratt, 2007). The catalytic FT process to produce diesel fuels is shown in the following reactions:

Syngas production

$$
\begin{array}{ll}
\mathrm{H}_{2} \mathrm{O}+\mathrm{CO} \rightarrow \mathrm{H}_{2}+\mathrm{CO}_{2} & \text { (watergas shift) } \\
\mathrm{H}_{2} \mathrm{O}+\mathrm{CH}_{4} \rightarrow \mathrm{CO}+3 \mathrm{H}_{2} & \text { (steam reforming methane) }
\end{array}
$$

FT Process

$$
\begin{array}{ll}
n \mathrm{CO}+(2 n+1) \mathrm{H}_{2} \rightarrow \mathrm{C}_{n} \mathrm{H}_{(2 n+2)}+n \mathrm{H}_{2} \mathrm{O} & \text { (paraffins) } \\
n \mathrm{CO}+2 n \mathrm{H}_{2} \rightarrow \mathrm{C}_{n} \mathrm{H}_{2 n}+n \mathrm{H}_{2} \mathrm{O} & \text { (olefins) }
\end{array}
$$

The complete diesel production process, including postproduction, is complex with numerous reactors and processes required. This is because direct FT products are a range of carbon numbers requiring upgrading to reach the desired carbon number 
for a homogenous fuel. This is less of an issue for $\mathrm{OME}_{\mathrm{x}}$ fuels due to their limited range of products and even less of an issue for DME production as a single component fuel, which requires a simple distillation.

According to (Becker et al., 2012) and (Hänggi et al., 2019) it takes $80 \mathrm{~kJ} / \mathrm{mol}$ of electrical energy to transform $1 \mathrm{~mol}$ of CO into the desired diesel product. Although only $85 \%$ of the initial FT products can be formulated into the desired diesel product (Oscar et al., 2009), the other $15 \%$ can be burnt as a heat source for processes such as distillation or the water gas shift reaction. The excess heat provided also provides the thermal requirements for the diesel production process (Hänggi et al., 2019). Due to the additional refining processes in FT synthesis, the well-to-miles efficiency is lower than for DME production. The energy consumed in the production is approximately $25 \%$ more (Hänggi et al., 2019) than that of DME (Oscar et al., 2009). On the other hand, FT fuels benefit from the lack of changes to the IC engine and the diesel supply infrastructure. However, these may not be significant enough to establish FT diesel as a more promising fuel for the decarbonisation of HGVs than DME.

\section{Oxymethylene Ether Synthesis}

From DME or methanol there are a variety of different synthesis pathways to OME as shown in Figure 5 (inspired by Baranowski, et al., 2017).

The most common synthesis pathway uses formaldehyde, as shown. However, the additional step required to synthesise formaldehyde, while it can be produced sustainably through partial oxidation of the $\mathrm{MeOH}$ (Ouda et al., 2017), decreases the well-to-wheel efficiency. The efficiency and economic viability of the process, no matter what route is taken, is also significantly reduced due to the many energy intensive fractional distillation processes required to separate the OMEs in order to make a fuel of equivalent compositions (Lautenschütz et al., 2016).

$$
\begin{gathered}
2 M e O H+F A_{\rightleftharpoons}^{H^{+}} O M E_{1}+H_{2} O \\
O M E_{n-1}+F A_{\rightleftharpoons}^{H^{+}} O M E_{n} \\
H F_{n}+M e O H_{\rightleftharpoons}^{H^{+}} O M E_{n}+H_{2} O
\end{gathered}
$$

Due to the increased complexity of the process and due to the required separation processes, OME synthesis has a lower exergy efficiency and a lower total fuel energy obtained from the same amount of $\mathrm{CO}_{2}$ and $\mathrm{H}_{2}$ in comparison to other synthetic fuels such as DME. However, it is comparable on this basis to that of FT diesel (Burre et al., 2019). Thus, unless and until further research and development leads to increased efficiency of the precursor of OME, DME appears to be a more efficient energy source.

\section{Dimethyl Ether Synthesis \\ Dimethyl Ether From $\mathrm{CO}_{2}$}

DME can be synthesised from $\mathrm{CO}_{2}$ via two main routes. By Route 1 it can be synthesised through the formation of syngas in the reverse water gas shift reaction (RWGSR) where it is then converted to DME through direct or indirect synthesis. Route 2 involves the synthesis of DME directly from $\mathrm{CO}_{2}$. Figure 6 shows a selection of potential routes to produce sustainable DME from a variety of sustainable carbon sources, with the key 'steppingstones' of most pathways, namely syngas and methanol, highlighted in green. This gives considerable scope for process development and new chemistries.

The Korean institute of Science and Technology developed a reactor sequence using the formation of syngas. It claimed that the reduction in the size of the methanol synthesis reactor

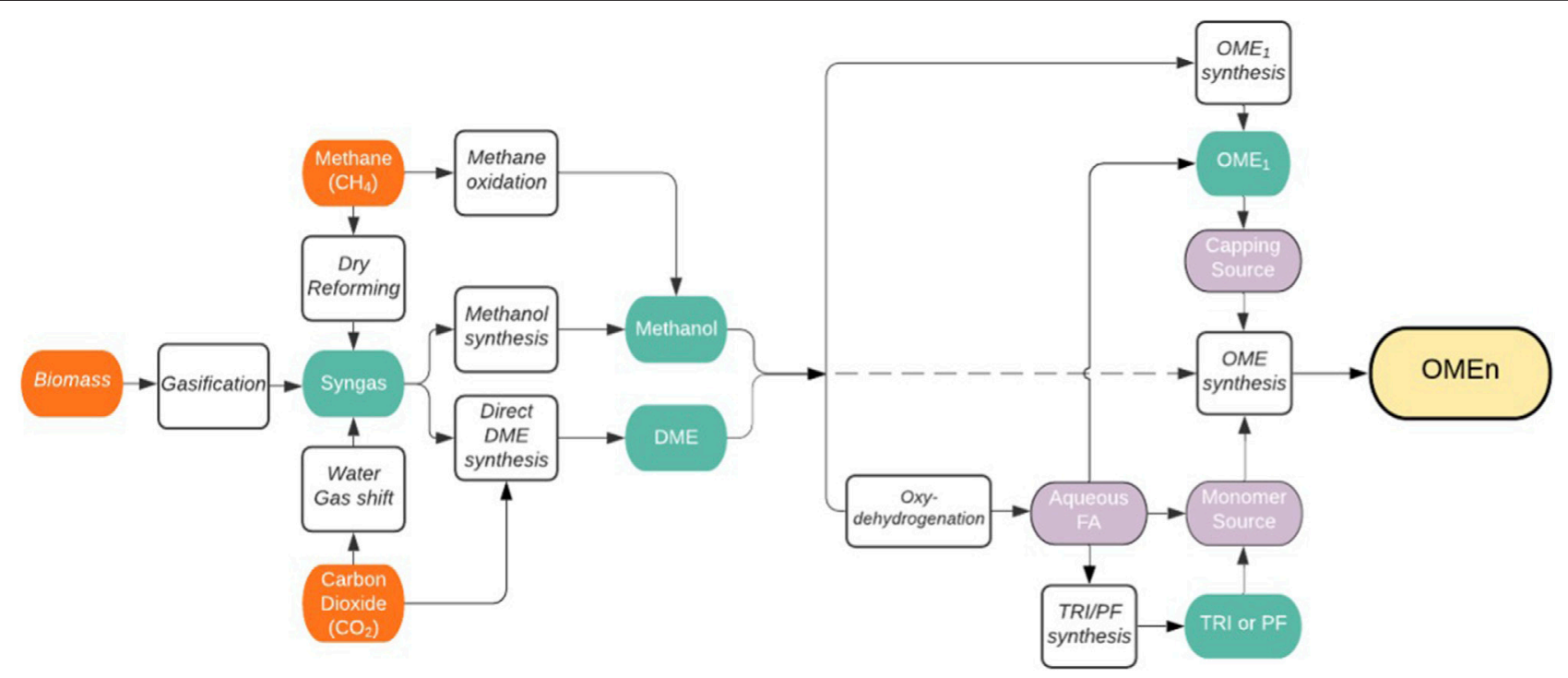

FIGURE 5 | Liquid phase synthesis of polyoxymethylene dimethyl ethers (OME) via methanol (derived from various sources) and DME. The depicted routes and reactants have been reported to be used for the production of $O M E_{n}$ with $n>1: O M E_{1}=$ dimethoxymethane, $T R I=$ trioxane, $P F=$ paraformaldehyde, $F A=$ formaldehyde, $\mathrm{DME}=$ dimethyl ether. 


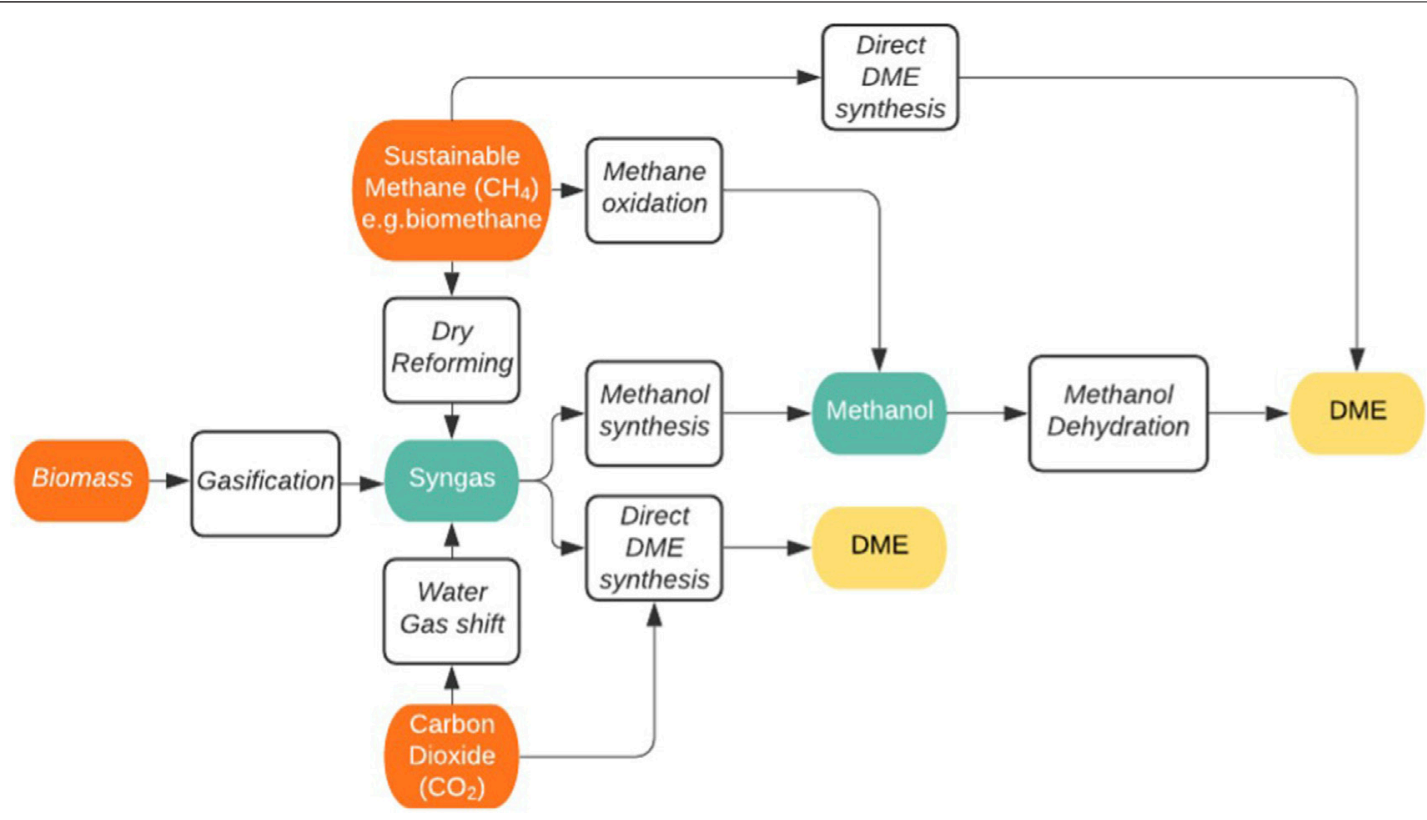

FIGURE 6 | Synthesis of DME using different carbon feedstocks.

and the increased efficiency in the production of methanol in this reactor led to the two-step procedure being the optimal method (Joo et al., 1999; Goeppert et al., 2014). Although the water produced during $\mathrm{CO}_{2}$ hydrogenation limited the formation and dehydration of methanol, thus resulting in a lower DME yield in comparison to CO (Azizi et al., 2014), more recent studies show that the higher oxidation power of $\mathrm{CO}_{2}$ in comparison to $\mathrm{CO}$ positively affects the active state of the catalyst for methanol formation, thus increasing the methanol yield, making it an equally viable pathway (Centi and Perathoner, 2013).

Evaluation of intermediate syngas production is not within the scope of this review. However, DME synthesis from $\mathrm{CO}_{2}$ without syngas can also be categorised into a single-step process (direct synthesis) or a two-step process (indirect synthesis) (Asthana et al., 2016). The basic principle of DME formation from $\mathrm{CO}_{2}$ is hydrogenation of $\mathrm{CO}_{2}$ to form methanol then the dehydration of methanol to form DME. In the indirect process two reactors and two catalysts are used, whereas in the direct process a single reactor and a bifunctional catalyst is used; the bi-functional catalyst carries two active sites, one for methanol formation and one for dehydration (Álvarez et al., 2017). The reactions for the formation of DME from $\mathrm{CO}_{2}$ are the hydrogenation of $\mathrm{CO}_{2}$, the reverse water gas shift reaction and the dehydration of methanol:

$$
\begin{array}{cc}
\mathrm{CO}_{2}+3 \mathrm{H}_{2} \rightleftarrows \mathrm{CH}_{3} \mathrm{OH}+\mathrm{H}_{2} \mathrm{O} & -49.5 \mathrm{~kJ} / \mathrm{mol}_{\mathrm{CO}_{2}} \\
\mathrm{CO}_{2}+\mathrm{H}_{2} \rightleftarrows \mathrm{CO}+\mathrm{H}_{2} & +41.2 \mathrm{~kJ} / \mathrm{mol}_{\mathrm{CO}_{2}} \\
\mathrm{CO}+2 \mathrm{H}_{2} \rightleftarrows \mathrm{CH}_{3} \mathrm{OH} & -90.6 \mathrm{~kJ} / \mathrm{mol}_{\mathrm{CO}} \\
2 \mathrm{CH}_{3} \mathrm{OH} \rightleftarrows \mathrm{CH}_{3} \mathrm{OCH}_{3}+\mathrm{H}_{2} \mathrm{O} & -23.4 \mathrm{~kJ} / \mathrm{mol}_{\mathrm{DME}}
\end{array}
$$

The combination gives the overall rection:

$$
2 \mathrm{CO}_{2}+6 \mathrm{H}_{2} \rightleftarrows \mathrm{CH}_{3} \mathrm{OCH}_{3}+3 \mathrm{H}_{2} \mathrm{O}
$$

In indirect synthesis, as methanol is synthesised separately and requires purification before the DME synthesis in a separate reactor, the economic viability of methanol production compared to DME is the main issue (Takeishi and Akaike, 2016). The dehydration/condensation of methanol to produce DME as a distinct step is discussed later. For the direct synthesis of DME using a 'one-pot' method, referring to simultaneous $\mathrm{CO}_{2}$ hydrogenation and methanol dehydration, the bifunctional catalyst requires a redox function to catalyse the $\mathrm{CO}_{2}$ and an acidic function to convert methanol to DME (Álvarez et al., 2017). The direct synthesis is theoretically more efficient and economical than the indirect method due to the reduction in process complexity and the thermodynamic equilibrium limitation of methanol synthesis decreasing by the consumption of methanol in the dehydration reaction. This moves the equilibrium in the forward direction (Vakili et al., 2011; Catizzone et al., 2017). As a result, the methanol purification unit required by indirect synthesis can be discarded as only one reactor is required in direct synthesis (Mollavali et al., 2008) and higher DME selectivity can be achieved (Aguayo et al., 2007).

The bifunctional catalyst historically used for DME synthesis is made up of $\mathrm{CuO} / \mathrm{ZnO} / \mathrm{Al}_{2} \mathrm{O}_{3}(\mathrm{CZA})$ for the $\mathrm{CO}_{2}$ hydrogenation and has been proven to be highly active (Ali et al., 2015) working alongside a solid acid catalyst HZSM-5 or $\gamma-\mathrm{Al}_{2} \mathrm{O}_{3}$ for the methanol dehydration to DME (Ren et al., 2019). As one of the key features that limits the effectiveness of bifunctional catalysts is the water production from the use of $\mathrm{CO}_{2}$ instead of $\mathrm{CO}$, recent research has been conducted to improve the stability of the hydrogenation catalyst. Zirconium modified 
CZA catalysts (Ren et al., 2020) and zeolite surface interaction with $\mathrm{CuO}-\mathrm{ZnO}-\mathrm{ZrO}_{2}$ (Bonura et al., 2020) have both been shown to increase the stability of the catalysts with significant improvements on catalytic stabilities being recorded.

\section{Thermodynamic Considerations}

According to Le Chatelier's principle and equations, using a lower temperature and higher pressure should promote the formation of the desired products as the exothermic nature of both methanol and DME production favour lower temperatures, whilst the endothermic nature of the reverse water gas shift reaction favours higher temperatures and is independent of pressure. As DME is synthesised with methanol as an intermediary product, the thermodynamic profiles are closely related with, as previously mentioned, the limitation of the $\mathrm{CO}_{2}$ conversion being removed by carrying out the methanol dehydration within the same catalytic system. Although the formation of olefins is possible in the production of DME from $\mathrm{CO}_{2}$, these can be minimised by optimising the catalysts (Catizzone et al., 2017) and shortening the residence time in the reactor (Moulijn et al., 2013) and therefore are not taken into thermodynamic consideration.

Thermodynamic profiling by (Shen et al., 2000) show that the combination of methanol synthesis and dehydration to DME indeed gave a consistently higher $\mathrm{CO}_{2}$ equilibrium conversion than the singular $\mathrm{CO}_{2}$ hydrogenation to methanol process. Kinetic modelling of this process (Aguayo et al., 2007; Qin et al., 2015) concluded, that the rate-determining step in DME synthesis was the methanol synthesis. Use of a Gibbs free energy minimisation approach verified this and supported Le Chatelier's principle, concluding that $\mathrm{CO}_{2}$ conversion and DME selectivity also increases with increasing total pressure (Ahmad and Upadhyayula, 2018). Although $\mathrm{CO}_{2}$ conversion increases with temperature above $350^{\circ} \mathrm{C}$, this signifies the move from equilibrium to kinetics controlling state of reaction completion. As a result of these competing influences, complete conversion to DME is close to impossible and there will always be a mixture of methanol and DME at equilibrium, meaning a separation process will always be required (Stangeland et al., 2018).

\section{Dimethyl Ether From Methane}

Rather than using $\mathrm{CO}_{2}$ as the direct source of the carbon for the DME, sustainably derived methane can alternatively be reformed or oxidized to form syngas or methanol respectively as shown previously in Figure 6. Either product can then be used to derive the DME fuel. The sustainably derived methane is generated by two main routes, anaerobic digestion or the Sabatier reaction of waste organic material, which will naturally in turn have been generated from photosynthetic air-captured $\mathrm{CO}_{2}$ at some point in the past. The Sabatier route involves the gasification of carbon-rich resources to generate pyrolysis gases; $\mathrm{CO}_{2}, \mathrm{CO}, \mathrm{H}_{2}, \mathrm{CH}_{4}$ and hydrocarbons, that can be further converted to commercially useful grades of methane using hydrogen and nickel-based catalysts (Sabatier and Senderens, 1902). The reactions are typically carried out at elevated temperatures and pressures $\left(400^{\circ} \mathrm{C}\right.$ and $\left.30 \mathrm{bar}\right)$ and proceed via complete hydrogenation of the carbon-species present:

$$
\begin{array}{ll}
\mathrm{CO}_{2}+4 \mathrm{H}_{2} \rightleftarrows \mathrm{CH}_{4}+2 \mathrm{H}_{2} \mathrm{O} & +165 \mathrm{~kJ} / \mathrm{mol} \\
\mathrm{CO}+3 \mathrm{H}_{2} \rightleftarrows \mathrm{CH}_{4}+\mathrm{H}_{2} \mathrm{O} & +206 \mathrm{~kJ} / \mathrm{mol}
\end{array}
$$

Side reactions typically include the generation of short hydrocarbon chains and elemental carbon.

A small number of plants using this principle have been operating for decades, converting coal into synthetic natural gas. Nevertheless, only one remains (in Beulah North Dakota) as low-cost shale gas has grown to dominate the non-sustainable fossil fuel market for natural gas (Kopyscinski et al., 2010; De Simio et al., 2013). New opportunities in this area remain, such as the possibility of using sustainable waste carbon resources like woodchip and other biomass which allow for the generation of renewable natural gas as a distinct product that can be immediately injected into the local national grid (Uchida and Harada, 2019; Vogt et al., 2019). By contrast, methane production from anaerobic digestion is widespread and typically carried out in individual small-scale digesters and on-site generation in suitable locations, particularly landfill sites. In the US in 2020, the total production of renewable natural gas via anaerobic digestion reached approximately $1.2 \mathrm{Mt}$ (Mintz and Voss, 2020). The methane produced through anaerobic digestion, by contrast to that produced in the Sabatier reaction, is typically mixed with significant quantities of $\mathrm{CO}_{2}$ and has a high water content. However, biogas drying and sweetening either by removal of this (originally biogenic) $\mathrm{CO}_{2}$ (Aepli et al., 2020) or by further conversion of that $\mathrm{CO}_{2}$ to more methane using renewable energy sources (Cave, 2020) is a developing industry.

While it may initially seem to be a circuitous route to generate DME from $\mathrm{CO}_{2}$-derived methane, given that methane is in a lower oxidation state than the DME, the potential benefit of using methane as an intermediate may be practical. For example, methane is readily transported by the existing natural gas pipeline networks in most developed economies. Furthermore, existing, highly developed and commercialised processes such as those used for drying natural gas, can be used directly. The initial cost-savings of being able to use this existing infrastructure have been discussed previously and it holds significant benefit, avoiding the necessity of the generation of a new fuel transport infrastructure. The sustainable methane, delivered via pipeline, could then be converted into DME at the desired site, allowing flexible development of the technology by separation of the direct or indirect $\mathrm{CO}_{2}$ utilisation from the fuel production. Once there is a supply of sustainable methane, it may be partially oxidized to methanol or syngas and then converted into DME as detailed previously, or even directly converted into DME by other means. For either partial oxidation route, selectivity to the desired product can be controlled by the reaction temperature. High reaction temperatures favour the production of syngas, whereas lower reaction temperatures promote the formation of methanol (Khirsariya and Mewada, 2013). However, the low reactivity of methane also makes the activation of the selective oxidation route challenging at low temperatures, resulting in a trade-off between 
reaction rate and selectivity to methanol. Supported copper-based catalysts have however shown promise, especially with water included or even used as the oxidant (Shi et al., 2018; Koishybay and Shantz, 2020).

Once the methanol is obtained, the formation of DME is carried out over a variety of acidic solid catalysts at $200-300^{\circ} \mathrm{C}$ and typically gives DME in high yield and selectivity through methanol dehydration. Example catalysts include supported iron and copper oxides and copper/zinc/zirconica catalysts, typically used in $\mathrm{CO}_{2}$ hydrogenation to methanol (Armenta et al., 2020). These catalysts can approach the maximum theoretical yields and selectivities for the reaction, which are limited by the presence of water (Migliori et al., 2020). Methane partial oxidation or reforming into syngas is a highly active area of research, both for hydrogen production and for further chemical synthesis, via syngas, from methane sources. The former is usually carried out by steam reforming, generating three molar equivalents of hydrogen per molecule of methane, with an additional molecule of hydrogen available from RWGS in tri-reforming. The latter route, where syngas with a lower hydrogen concentration is desired, can be achieved through dry autothermal reforming, which uses further carbon dioxide with the methane at high temperatures to generate 1:1 syngas.

$$
\begin{gathered}
\mathrm{CH}_{4}+\mathrm{H}_{2} \mathrm{O} \rightleftarrows 3 \mathrm{H}_{2}+\mathrm{CO} \quad \text { Steam Reforming } \\
\mathrm{CH}_{4}+2 \mathrm{H}_{2} \mathrm{O} \rightleftarrows 4 \mathrm{H}_{2}+\mathrm{CO}_{2} \quad \text { Tri Reforming } \\
2 \mathrm{CH}_{4}+\mathrm{O}_{2}+\mathrm{CO}_{2} \rightleftarrows 3 \mathrm{H}_{2}+3 \mathrm{CO}+\mathrm{H}_{2} \mathrm{O} \quad \text { Autothermal Reforming }
\end{gathered}
$$

This is carried out using a wide variety of catalysts, typically including supported nickel but also iron, calcium, zinc and cerium-based catalysts (Gao et al., 2020a; Ugwu et al., 2020; Dang et al., 2021; Shah et al., 2021) among others. Along with this variety of catalysts, a wide variety of conditions are also used with temperatures ranging from $550^{\circ} \mathrm{C}$ to $2,000^{\circ} \mathrm{C}$, however very high yields (>95\%) and selectivities (>95\%) are typically achieved. The subsequent conversion of syngas to DME proceeds as detailed in the previous section on the direct route for DME from $\mathrm{CO}_{2}$.

Finally, it is also possible to use methane as a direct precursor, rather than as a syngas or methanol source. This involves the activation of methane using a halogen radical to generate the methyl halide, followed by a precious-metal catalysed hydrationdimerisation process. Of note here is the potential for a lowtemperature route to DME, with the hydration-dimerisation of methyl bromide to DME shown to occur with good yield and selectivity at just $150-180^{\circ} \mathrm{C}$ using a simple ruthenium catalyst (Xu et al., 2005). While the initial bromination step in that research required temperatures of $530-560^{\circ} \mathrm{C}$, which were achieved through self-heating by partial methane combustion, the dimerization process could also be fuelled by low temperature methane halogenation through photochemical, electrochemical or even mechanochemical means, where a chlorine-rich substrate is milled in the presence of methane to selectively generate methyl chloride at temperatures below $150^{\circ} \mathrm{C}$ (Bilke, et al., 2019). Indeed, this route has been recently demonstrated for an electrochemical methane-to-methanol conversion at $130^{\circ} \mathrm{C}$ and 46.5 bar $\mathrm{CH}_{4}$ over platinum which proceeds via a methyl chloride intermediate in a similar fashion (Kim and Surendranath, 2019).

\section{HYDROGEN SOURCES}

In order for these synthetic routes to be truly carbon neutral, the hydrogen sources also need to be derived from non-fossil sources. These sources include thermochemical water decomposition (Mehrpooya and Habibi, 2020), water electrolysis and biomass gasification (Badwal et al., 2014) as shown in Figure 7. As mentioned earlier, any energy required in the production of hydrogen and the synthesis of the DME must also be derived from non-fossil, renewable energy sources. The synthesis of $\mathrm{DME}$ from $\mathrm{CO}_{2}$ requires the addition of hydrogen, as six hydrogen molecules are required for every two molecules of $\mathrm{CO}_{2}$ to produce one molecule of DME. The highest heating value for $\mathrm{H}_{2}$ is $142 \mathrm{MJ} / \mathrm{kg}$ (Chen et al., 2011), which compares well with other known fuels and is why it is seen as not only a feedstock for making other synthetic fuels but as a potential fuel itself.

As mentioned previously, in order to ensure that the DME produced is carbon neutral the source of the hydrogen and any electricity/heat energy used in the production must come from renewable sources (Kothari et al., 2008). This means that conventional hydrogen production from heavy hydrocarbons, coal gasification and fossil natural gas steam reforming cannot be considered, as $\mathrm{CO}_{2}$ is the largest emission from the process (Kothari et al., 2004). With only 5\% of hydrogen currently being produced by sources other than natural gas and coal (IRENA, 2019) and the leading practice being electrolysis of water, which is also the most energy consuming route (Holladay et al., 2009), it is necessary to look at other methods such as producing hydrogen from biomass and to compare their efficiencies.

It can be seen that water is always crucial for hydrogen generation, however, in many of these cases a very high purity of water is required for good conversion yields (Gandia, et al., 2013). Since globally clean water is an 'under-pressure resource', especially in arid areas which also contain solar primary energy resources (Saleth and Dinar, 2004), the location and distribution of any putative large scale sustainable hydrogen production requires serious consideration.

\section{Hydrogen From Water}

Water splitting or cracking to produce hydrogen is completed through three predominant methods; electrolysis, thermolysis and photo-electrolysis. The simple base principle is water is divided into its individual components; oxygen and hydrogen-requiring either free energy or high temperatures (Kothari et al., 2004). The basis of water electrolysis is the movement of ions promoted by an external circuit through an electrolyte to promote the splitting of water in an electrolysis cell (electrolyser) (Eq. 20) (Bhandari et al., 2014). In the electrolyser, 


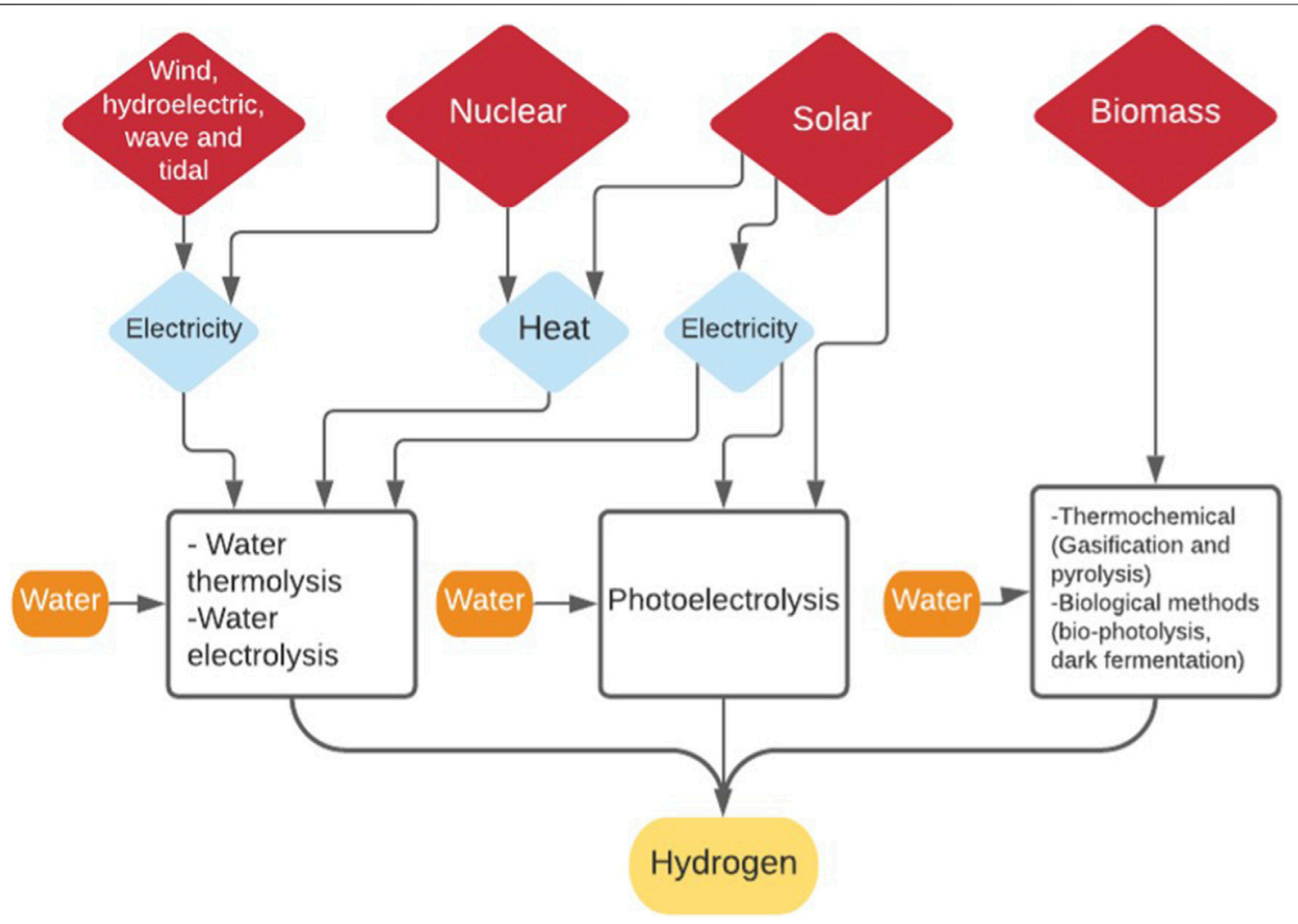

FIGURE 7 | Various routes for the sustainable (or low-carbon) production of hydrogen

two electrodes are placed in the water thus facilitating the external circuit and the formation of ions/electrons on either electrode:

$$
\begin{gathered}
\text { Cathode }: 2 \mathrm{H}_{2} \mathrm{O}+2 e^{-} \rightarrow \mathrm{H}_{2}+2 \mathrm{OH}^{-} \\
\text {Anode }: 4 \mathrm{OH}^{-} \rightarrow \mathrm{O}_{2}+2 \mathrm{H}_{2} \mathrm{O}+4 e^{-} \\
\text {Overall : } \mathrm{H}_{2} \mathrm{O}+\text { direct current electricity } \rightarrow \mathrm{H}_{2}+\frac{1}{2} \mathrm{O}_{2}
\end{gathered}
$$

There are different types of electrolysis cells, such as polymeric electrolyte membrane electrolysers, alkaline electrolysers and solid oxide electrolysers among those in production and development. Although similar in their goal they use slightly different methods, catalysts and materials to try to formulate the most efficient and cheapest process, whilst also achieving the purity of hydrogen required. As low-temperature water electrolysis can take advantage of relatively low space requirements and exploiting the existing infrastructure for the electricity and water use, it can rapidly be added to an existing plant (FreedomCAR and Fuel Partnership, 2009). The downside of water electrolysis is its efficiency of $60-80 \%$ (Shiva Kumar and Himabindu, 2019) and the high capital cost due to catalyst/ membrane poisoning depending on the water source and the low hydrogen evolution rate compared to the high energy consumption, especially prevalent if sea water is used (Shi et al., 2020). This means its economic compatibility is low. The energetic efficiency (energy obtained from the hydrogen fuel per unit of electrical energy required) is around $56-73 \%$ (Turner et al., 2008). In 2008, the cost of producing sustainable hydrogen to reach an equivalent fuel price to that of fossil-derived hydrogen required access to electricity prices as low as $\$ 0.045$ $\$ 0.055 \mathrm{kWh}^{-1}$ (Turner et al., 2008), no transportation of energy costs to be included, and the hydrogen being produced at a local wind power site as the primary energy source.

Water electrolysis requires $47.99 \mathrm{kWh}$ per $\mathrm{kg} \mathrm{H}_{2}$ (MartínezRodríguez and Abánades, 2020). This is around four times higher than the energy required to produce hydrogen through steam reforming. Although research and development are leading to more energy efficient electrolysers, this still proves a barrier to an economically viable production method.

Thermolysis is the direct one-step method of decomposing water into its constituent molecules governed by homogenous kinetic mechanisms (da Silva Veras et al., 2017).

$$
\mathrm{H}_{2} \mathrm{O}+\text { heat } \rightarrow \mathrm{H}_{2}+\frac{1}{2} \mathrm{O}_{2}
$$

In order to achieve the thermal decomposition, the temperature needs to reach over 2,500 K (Dincer and Acar, 2015), which theoretically allows a $>4 \%$ dissociation level at atmospheric pressure (Baykara, 2004). This increases at even higher temperatures, with $64 \%$ dissociation achieved at $3,000 \mathrm{~K}$ and 1 bar, (Dincer and Acar, 2015). As this is a reversible reaction, the recombination of the end products needs to be avoided. Common methods include rapid cooling of the gaseous mixture through direct contact with cold fluid (Lede et al., 1982). Having temperatures in both extremes increases the running cost of the facility thus increasing the cost of the hydrogen produced. In order not to require extreme cooling, the use of palladium 
membranes can be used to avoid the recombination of $\mathrm{H}_{2}$ and $\mathrm{O}_{2}$ (Dincer and Acar, 2015).

In order to obtain the high temperature required for this process, the renewable energy sources need to be evaluated. However, the scaling up of the process is believed to increase thermal efficiency (Holladay et al., 2009). The only renewable energy or low carbon sources currently generally capable of producing the heat required for this process are nuclear energy and concentrated solar power providing high temperature steam (Dincer and Acar, 2015; Dincer and Safari, 2020). The overall efficiency of the process is dependent on the renewable energy source and can vary between $17-45 \%$, with a nuclear heat source providing a higher overall efficiency than a solar heat source (Nikolaidis and Poullikkas, 2017). As heat energy and electrical energy are not equivalent, with $1 \mathrm{~J}$ of electrical energy being equal to around $4 \mathrm{~J}$ of heat energy a $\mathrm{kWh}$ per $\mathrm{kg} \mathrm{H}_{2}$, comparison is not effective. However, comparisons based on cost of the hydrogen produced can be made at 2.17-2.63 United States $\$$ per $\mathrm{kg} \mathrm{H}_{2}$. If it were decided to incorporate a hydrogen production plant into the DME production plant instead of outsourcing the hydrogen production, the excess heat released from the exothermic DME synthesis reactions could, in principle, contribute towards the heat require for thermolysis.

Photo-electrolysis or the photoelectrochemical (PEC) splitting of water, uses the absorption of photons from sunlight to directly decompose water on irradiation, using semiconductors. An advantage of the PEC cell is that it combines the water electrolysis and solar energy absorption into a single monolithic device (Chaubey et al., 2013; Dincer and Safari 2020).

$$
\mathrm{H}_{2} \mathrm{O}+\text { photons }+ \text { electricity } \rightarrow \mathrm{H}_{2}+\frac{1}{2} \mathrm{O}_{2}
$$

The basis of PEC is that a photoelectrode absorbs photons from solar irradiation with enough energy to excite the electrons from the valence shell to the conduction band (Yang et al., 2017). The semiconductor is immersed in a water-based electrolyte where the energy released when the electrons return to the valence band is used to energise the water and facilitate the hydrogen production as water is split on the semiconductor surface (Turner et al., 2008). Depending on the conductor material, the density of the electric current produced varies between 10 and $30 \mathrm{~mA} \mathrm{~cm}$ of the semiconductor. This facilitates a lower voltage requirement that leads to higher efficiencies (Christopher and Dimitrios, 2012). A minimum energy of $1.36 \mathrm{eV}$ is required to split a water molecule and, including the electron transfer induced losses, a photon of 1.6-2.4 eV is required to be absorbed for effective photo-electrolysis (Roger, Shipman and Symes, 2017). This corresponds to wavelengths within the visible light spectrum, thus providing a potentially reliable energy feedstock and electrolysis efficiency levels reaching $91 \%$ (Christopher and Dimitrios, 2012). The overall hydrogen production efficiency of $10-12.4 \%$ (Turner et al., 2008; Christopher and Dimitrios, 2012) is promising for future production possibilities, with this efficiency level in 2007 corresponding to only requiring 4,000 square miles of photoreceptors for the entire United States vehicle fleet.

\section{Hydrogen From Biomass}

The two major categories of hydrogen production from biomass are thermochemical technology routes [which include gasification and pyrolysis (Zhang, 2010; Sanna, 2013)] and biological treatments [which includes bio-photolysis and fermentation (non-exclusively) (Levin, 2004)]. The thermochemical conversion of biomass to hydrogen is the most advanced and established technological production method (Lepage et al., 2021). Lignocellulosic biomass is the main feedstock for these processes, although it is currently expensive to produce, thus contributing to the higher production cost of hydrogen from thermochemical biomass. There is an indication that these prices will reduce in the future as a result of the environmental policy price impact on fossil resources (Fiorese et al., 2014). As the hydrogen content of biomass is only $6-6.5 \%$ depending on the feedstock, in comparison to $25 \%$ in natural gas (Kothari, et al., 2004), previously there has not been economic reason to make the swap to biomass. However, reduction in net $\mathrm{CO}_{2}$ makes this a feasible production option.

Biomass gasification is a mature technology which adopts the same principles as coal gasification. Gasification and pyrolysis are related processes where the thermochemical conversion of solid biomass fuel into syngas uses steam, oxygen or air as a medium for gas generation at a level lower than that required for full stoichiometric combustion (Holladay et al., 2009; Sansaniwal et al., 2017). Gasification is a highly endothermic process, operating at temperatures between $500-1,400^{\circ} \mathrm{C}$ and from atmospheric pressure up to 33 bar depending on plant scale, type of reactor, initial feedstock material and the function of the syngas produced (Iribarren et al., 2014). Within biomass gasification, the biomass mass goes through three phases: drying, pyrolysis and reduction (Lepage et al., 2021). The gasification reaction can be achieved using air, oxygen and oxygen enriched air.

It is possible for a biorefinery to stop processing the biomass after pyrolysis producing three products; syngas, bio-oils and char. This allows the products to be separated and used for multiple end products such as such as the products of light olefins from the catalytic cracking of bio-oil (Arregi et al., 2018). However, as the required output is the hydrogen, for maximum biomass to hydrogen efficiency, full gasification must take place. Although hydrogen is a direct product of gasification, in order for the maximum hydrogen content to be extracted from this process, thus making it more efficient, the syngas received from gasification then goes through a water gas shift reactor to obtain the maximum hydrogen possible (Holladay et al., 2009).

Any excess products can be burnt as a cheap source of electricity or heat. This contributes to the lower cost of hydrogen production of 1.21-3.5 United States $\$ / \mathrm{kg} \mathrm{H}_{2}$ (Lepage et al., 2021), depending on the feedstock, scale of production, catalyst and methods used. Efficiencies can vary from 30-70\% based on the LHV (Binder et al., 2018).

Biological treatments or processes are methods to produce hydrogen which depends on the use of enzymes to catalyse hydrogen formation (Levin, 2004). The biological treatments can be spilt into the biological splitting of water (direct and 
indirect bio-photolysis) and the fermentation of biomass to produce hydrogen. In comparison to the thermochemical biological methods to produce hydrogen, biological treatments tend to operate at atmospheric pressure and temperatures between $30-60^{\circ} \mathrm{C}$ (Lepage et al., 2021). Taking account of the ability of the microorganism to be regenerated by replication (Henstra et al., 2007) reduces the catalyst turnover resulting from degradation in high temperatures through thermochemical processes.

\section{Bio-photolysis}

Bio-photolysis utilises the photosynthetic abilities in green algae or cyanobacteria in a method adapted for the generation of hydrogen gas instead of carbon containing biomass (Kothari et al., 2004). The process is split into two methods direct and indirect photolysis. Direct bio-photolysis is the process of green algae splitting water via photosynthesis into a hydrogen ion and oxygen, using the ability of the algae to transform solar energy into chemical energy (Melis et al., 2000). The reaction is governed by two photosynthetic systems PS I and PS II (Figure 8). These systems harvest light energy under anaerobic conditions, transferring $\mathrm{H}_{2} \mathrm{O}$ electrons to ferredoxin (Kim and Kim, 2011). The hydrogenase enzyme then catalyses the reaction of the reduced ferredoxin acting as an electron donor providing an electron to the hydrogen ion, forming hydrogen gas (Eroglu and Melis, 2011). This can be categorised in the following reaction scheme (Bič́ková and Straka, 2012):

The major disadvantage of this system for producing hydrogen is that in order for the hydrogenase to function efficiently, anaerobic conditions are required as it is very sensitive to oxygen (Prince and Kheshgi, 2005). However, the reaction also produces oxygen as a product so maintaining complete anaerobic conditions is a priority for researchers. Research is on-going to increase the yield of hydrogen by depleting the production of oxygen, however current methods such as the addition of a sulphate solution also supresses hydrogen production (Williams and Bees, 2013). Progress has been made with recent research leading to an increase in light utilisation energy from 5 to $15 \%$, with further room for improvement possible by increasing the scale of the algal bioreactors (Show et al., 2011). As the process does not require vast amounts of electricity, the price of the hydrogen produced is around $2.13 \$ / \mathrm{kg} \mathrm{H}_{2}$ (Hallenbeck and Benemann, 2002; Kayfeci et al., 2019) this is comparable to some fossil-based methods, however production on a large scale remains a barrier to mass rollout.

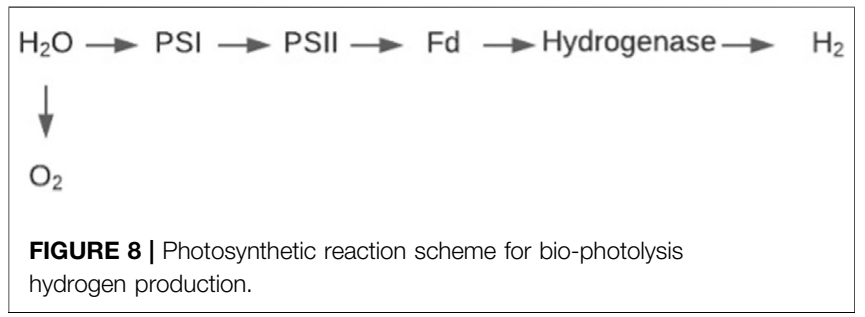

Indirect bio-photolysis is sometimes also referred to as aerobic dark fermentation as it consists of two major steps. The first comprises of the photosynthesis of cyanobacteria to produce glucose in a conventional manor. The second, involves the aerobic dark fermentation of the glucose to produce hydrogen as seen in Eqs 23, 24 (Chaubey et al., 2013):

$$
\begin{aligned}
& 6 \mathrm{H}_{2} \mathrm{O}+6 \mathrm{CO}_{2}+\text { photons } \rightarrow\left(\mathrm{C}_{6} \mathrm{H}_{12} \mathrm{O}_{6}\right)_{n}+6 \mathrm{O}_{2} \\
& \left(\mathrm{C}_{6} \mathrm{H}_{12} \mathrm{O}_{6}\right)_{n}+12 \mathrm{H}_{2} \mathrm{O}+\text { photons } \rightarrow \mathrm{H}_{2}+6 \mathrm{CO}_{2}
\end{aligned}
$$

The reactions are catalysed by both hydrogenase and nitrogenase, as cyanobacteria are capable of fixing atmospheric nitrogen (Benemann, 2000). Cyanobacteria are the ideal candidates for this process with a maximum of $16.35 \%$ light efficiency (Prince and Kheshgi, 2005), however in practice efficiency is only $1-2 \%$, so further development is required before this process can become commercially viable (Chaubey et al., 2013). Although the low efficiency leaves this method in its conceptual phase, calculations have been carried out which place the price of hydrogen needed to make the processes economically viable at $1.42 \$ / \mathrm{kg}$ of $\mathrm{H}_{2}$ (Hallenbeck and Benemann, 2002; Kayfeci et al., 2019).

\section{Dark Fermentation}

Dark fermentation is the process of producing hydrogen through anaerobic bacteria being grown on carbohydrate rich substrates without accesses to light (Levin, 2004; Ghavam et al., 2021). It requires temperatures between $25^{\circ} \mathrm{C}$ and $80^{\circ} \mathrm{C}$ (Lepage et al., 2021) depending on the strains. The products of this process are mostly $\mathrm{CO}_{2}$ and $\mathrm{H}_{2}$ with other gas products being released such as $\mathrm{CH}_{4}$ and $\mathrm{H}_{2} \mathrm{~S}$. The combination of products and their ratios depends on the quality of the substrate used. Due to the production of other products, the $\mathrm{H}_{2}$ yield is lower than that of bio-photolysis, thus contributing to the lower efficiency of the process (Soares et al., 2020). Glucose could be an ideal feedstock, however due to its high price it makes the process uneconomical. Lignocellulosic biomass has been identified as a promising feedstock although the requirement of pre-treatment increases the price of the hydrogen required to make the process economically viable (Soares et al., 2020). The amount of hydrogen produced also depends on the $\mathrm{pH}$ of the fermentation atmosphere with the maximum hydrogen yields occurring at a pH of 5-6 (Fang and Liu, 2002).

Dark fermentation has significant advantages such as being a light independent. It does not require large land use (such as those depending on solar energy), it can capitalise on being able to use a multitude of different feedstocks and it has high rates of hydrogen production unsurpassed by other biological processes (Chaubey et al., 2013; Soares et al., 2020) with values ranging from 184 to 2,710 $\mathrm{ml}$ hydrogen $\mathrm{L}^{-1} \mathrm{~h}^{-1}$ reported (Turner et al., 2008). Dark fermentation has a biomass conversion efficiency of $60-80 \%$ assuming that the maximum yield of glucose as a feedstock is catabolised (Kovacs et al., 2006), which contributes to a hydrogen cost of $2.57 \$ / \mathrm{kg}$ Nikolaidis and Poullikkas, 2017).

The optimal hydrogen source for DME production will vary depending on the location of the plant, the availability of the feedstock and the price and availability of the primary energy source. This can change depending on location, for example (as 
TABLE 3 | Hydrogen cost as a function of different processes (Kayfeci et al., 2019; Nikolaidis and Poullikkas, 2017; Kayfeci et al., 2019 and Lepage et al., 2021).

\begin{tabular}{|c|c|c|c|}
\hline Process & Energy source & Feedstock & Hydrogen cost $\$ / h g$ \\
\hline \multirow[t]{2}{*}{ Water electrolysis } & Wind & Water & $5.89-6.03$ \\
\hline & Nuclear & Water & $2.35-7.0$ \\
\hline \multirow[t]{2}{*}{ Thermolysis } & Solar & Water & $2.17-2.63$ \\
\hline & Nuclear & Water & $7.98-8.40$ \\
\hline Photo electrolysis & Solar & Water & 10.36 \\
\hline Biomass gasification & Internally generated steam & Biomass & $1.21-3.5$ \\
\hline Direct bio-photolysis & Solar & Algal biomass + water & 2.13 \\
\hline Indirect bio-photolysis & Solar & Algal biomass + water & 1.42 \\
\hline Dark fermentation & & Organic biomass & $2.37-2.80$ \\
\hline
\end{tabular}

explained above) France produces a lot of low-carbon electricity due to their vast nuclear programme. Producing hydrogen through water electrolysis from a nuclear source will be cheaper as the sustainable electricity is cheaper. The hydrogen sources discussed in this review are non-exhaustive and are meant to provide a brief overview. Comparisons can be seen in Table 3 .

\section{CARBON CAPTURE AND UTILISATION TECHNOLOGIES}

In order to access $\mathrm{CO}_{2}$, vital as the required feedstock for DME synthesis, it initially needs to be captured, compressed and transported from $\mathrm{CO}_{2}$ point sources. As global political pressure regarding $\mathrm{CO}_{2}$ output has increased on energy and industrial processes, there has been increased research and implementation of carbon capture and storage (CCS) technologies. This involves the selective removal of $\mathrm{CO}_{2}$ from gas streams, after which it is then compressed and transported to geological storage solutions such as exhausted natural gas reservoirs and saline aquifers, where in principle the $\mathrm{CO}_{2}$ can be stored for geological periods, instead of adding to the growing atmospheric concentration (Al-Mamoori et al., 2017). However, in spite of government subsidies, the high costs of CCS (with 75\% of the total cost coming from the primary capture and compression of the $\mathrm{CO}_{2}$ ) have inhibited large scale industrial roll-out. Therefore, Carbon Capture and Utilisation (CCU), where the $\mathrm{CO}_{2}$ is used as a feedstock after capture and possibly compression and can be used by the industrial and energy sector as a valuable product instead of an expensive waste; a concept that makse it a much more attractive alternative (Styring et al., 2011; Styring et al., 2014; North and Styring, 2019a; North and Styring, 2019b).

The industrial sector accounted for almost $40 \%$ of global $\mathrm{CO}_{2}$ emissions in 2018 (after allocating electricity and heat emissions across final sectors) (IEA, 2020a). This makes the industrial sector the prime location to install CCU technologies for the production of $\mathrm{CO}_{2}$ as a valuable feedstock, along with fossil-fuel power plants (Markewitz et al., 2012). As well as offsetting $\mathrm{CO}_{2}$ emissions by utilising the $\mathrm{CO}_{2}$ for chemical synthesis of other products, in this case DME, it has been suggested that CCU can further reduce the emissions by forgoing conventional production strategies. For example, the use of $1 \mathrm{~kg} \mathrm{CO}$ for the production of $\mathrm{CO}_{2}$-based polymers can overall reduce emissions totalling $3 \mathrm{~kg} \mathrm{CO}$ when compared to the non-CCU route (von der Assen and Bardow, 2014; Kätelhön et al., 2019). Michailos et al. (2019) have also considered the techno-economics of integrated carbon capture and DME production in the context of a positive life cycle impact.

Generally, there are three main methods for $\mathrm{CO}_{2}$ capture from industry; pre-conversion/combustion, post-conversion/ combustion and oxy-fuel combustion (Kanniche et al., 2010). These can be seen in Figure 9, adapted from Cuéllar-Franca and Azapagic, (2015):

Post-combustion carbon capture involves the separation of $\mathrm{CO}_{2}$ from the waste gas stream after the combustion of the carbon source, or conversion of the carbon source in the formation of the target product, e.g. energy or steel. When used in power plants, the process is known as post-combustion capture, however when used in industrial plants it can be referred to as post-conversion capture. Post-conversion CCU requires the least amount of retrofitting to the existing facilities and is typically regarded as the most efficient strategy (Gao et al., 2020b). Using aqueous amine solution to capture $\mathrm{CO}_{2}$ through absorption is the current industrial standard for post-combustion carbon capture (Nwaoha et al., 2017). However, as the solution has a high heat capacity and results in significant material losses, it causes elevated costs leading to a need for a more economical system (Patel, Byun and Yavuz, 2017). Many other post combustion methods have been developed as alternatives to amine solution separation such as absorption in other solvents, adsorption by solid sorbents (Patel, Byun and Yavuz, 2017), separation via membranes and cryogenic separations. The optimum overall strategy will depend on available energy at the $\mathrm{CO}_{2}$ source. For example, the energy requirement needed for monoethanolamine (MEA) absorption can be met to facilitate lower energy costs if the plant has a combined heat and production feature. However, this is not the case in some industrial processes such as cement plants, as insufficient heat is produced (Kuramochi et al., 2012). An issue that needs to be addressed is that the separation processes can be challenging due to the low partial pressure of $\mathrm{CO}_{2}$ in flue gas resulting in a low $\mathrm{CO}_{2}$ driving force and a large volume of gas to be treated (Zhang et al., 2019). For the process to be truly carbon neutral, the energy required for CCU either needs to come from the process itself in the form of waste heat or from a renewable energy source.

Pre-combustion/conversion carbon capture purifies $\mathrm{CO}_{2}$ generated during an intermediate process, resulting in the production of less end- $\mathrm{CO}_{2}$. Examples include the gasification 


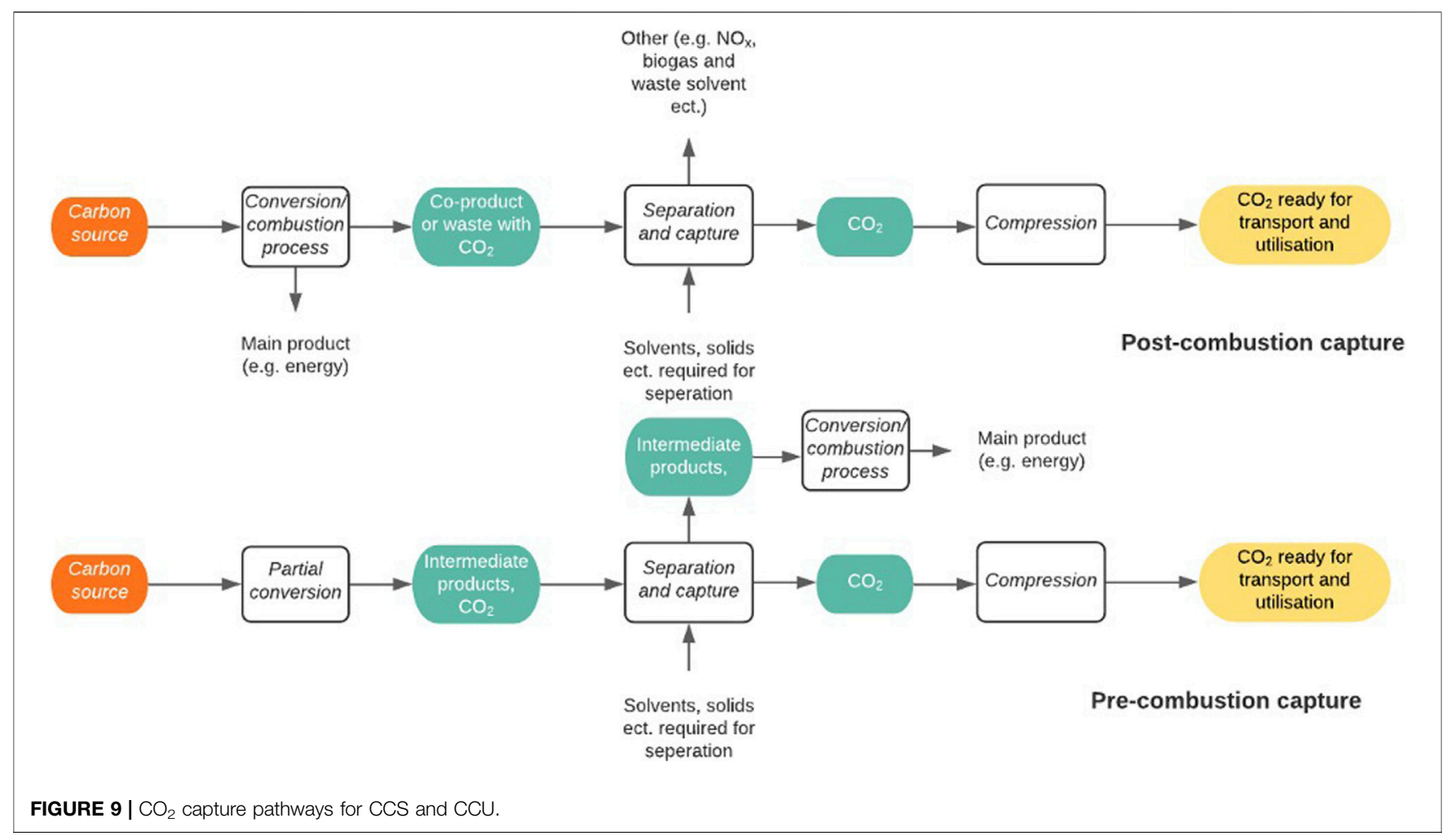

of coal, reforming of natural gas and the production of ammonia (Jansen et al., 2015). As the majority of pre-combustion carbon capture involves the removal of $\mathrm{CO}_{2}$ from syngas, the prime separation method will be dependent on the partial pressure of $\mathrm{CO}_{2}$ in the treated gas. An example of industrial utilisation is the separation of $\mathrm{CO}_{2}$ from $\mathrm{H}_{2}$ before it can be used in ammonia synthesis. This usually occurs with the use of MEA as the absorption mechanism (Global Carbon Capture and Storage Institute, 2012). However, these methods are similarly disadvantaged to post-conversion/combustion technologies in that the regeneration of chemical solvents such as MEA cause an incurred energy penalty to the system, thus decreasing the overall efficiency (Cuéllar-Franca and Azapagic, 2015). The use of physical solvents decreases the energy required for the $\mathrm{CO}_{2}$ capture. It is therefore the primary method for integrated gasification in combined cycle plants, which are being used to produce 'clean coal', where the physical solvents such as Selexol and Rectisol are used (Porter et al., 2017). For all CCU methods, it needs to be noted that any energy being supplied to the system to aid in the carbon capture needs to be renewable and therefore not be a process that itself produces $\mathrm{CO}_{2}$.

Oxy-fuel combustion does not have a conversion alternative as it can only be applied to processes involving combustion. The principle uses pure oxygen for the combustion instead of air. This avoids the dilution of the flue gas with other gasses such as nitrogen, resulting in an exhaust gas with a significantly increased partial pressure of $\mathrm{CO}_{2}$ (Borgert and Rubin, 2017). Partial recycling of the flue gas into the boiler is required to moderate the flame temperature which would otherwise burn excessively high as a result of burning in pure oxygen (Porter et al., 2017).
Although the $\mathrm{CO}_{2}$ does have a much higher partial pressure in the exhaust gas, there are still traces of water vapour, particulate matter and other pollution gases, which require a separation process before the $\mathrm{CO}_{2}$ can be dried and compressed for transport (Najera et al., 2011). In order to retrofit a plant for oxy-fuel combustion carbon capture, it requires an air separation unit (which is often cryogenic) to provide pure oxygen from air and a $\mathrm{CO}_{2}$ compression and separation unit and an exhaust gas recycle (Porter et al., 2017).

Although these three methods are not the only methods to capture $\mathrm{CO}_{2}$ for utilisation, they are the main methods used from industrial and energy producing sources. Other sources include the $\mathrm{CO}_{2}$ produced from biological processes and brewing sources, however these come with their barriers for the making of synthetic fuels. Biological sources of $\mathrm{CO}_{2}$ come with more sulfur and a higher moisture content than energy and industrial sources (Thema et al., 2019). There is competition for the high purity of $\mathrm{CO}_{2}$ produced from brewing for use in the fizzy drink industry, driving up the price of the $\mathrm{CO}_{2}$, making this $\mathrm{CO}_{2}$ not economically viable for synthetic fuel production. Porter et al. (2017) produced a comparative report of the cost and performance of carbon capture methods based on the three methods discussed in this review.

Once the $\mathrm{CO}_{2}$ has been compressed and purified to the specification required by the consumer, in this case to produce DME, the $\mathrm{CO}_{2}$ must be transported to the synthetic fuel plant. As any transportation of $\mathrm{CO}_{2}$ will incur costs, the most economical option would be to synthesise the DME on the same site as the $\mathrm{CO}_{2}$ is captured. This approach can also take advantage of the economies of scale of the existing plant where 
the $\mathrm{CO}_{2}$ is being captured, as well as any excess heat from the plant, recycled where necessary in the DME synthesis process. If the $\mathrm{CO}_{2}$ does need to be transported, a pipeline infrastructure is required, and currently there is no $\mathrm{CO}_{2}$ infrastructure in the United Kingdom for $\mathrm{CO}_{2}$ from industrial flue gases (Ecofys, 2017). However, $\mathrm{CO}_{2}$ transportation plans exist in Europe and retrofitting of existing infrastructure by repurposing oil and gas pipelines is being considered. This approach represents a cost of around $1-10 \%$ of the cost of building an entirely new $\mathrm{CO}_{2}$ pipeline (IOGP, 2019). While implanting CCU decreases the overall plant efficiency for the initial product, the addition of CCU creates another valued product whilst complying with strict government regulation imposed to reduce the level of $\mathrm{CO}_{2}$ emissions to the atmosphere.

\section{CONCLUSION}

Dimethyl ether (DME) is discussed in this review as a future fuel that can help facilitate the transition from a fossil-fuel based economy to a net zero economy. DME is a single molecule fuel (unlike fossil fuels which are complex mixtures) and while having half the energy density of diesel it has several benefits.

- It contains only two carbon atoms and so burns almost completely, so NOx emissions are low.

- As the fuel is non-fossil-based there are also no SOx emissions.

- Because there are no carbon-carbon (C-C) bonds, only carbon-oxygen ( $\mathrm{C}-\mathrm{O})$ bonds, there is no soot formation and so low PM emissions.

- Furthermore, due to its favourable cetane number it can be used directly in CI engines.

- Some fuel delivery modifications are needed as DME is a gas, but the interventions are similar to those already available for LPG fuels.

- Oxymethylene ethers (OMEx) are higher homologues where $\mathrm{x}$ represents additional oxymenthylene $\left(-\mathrm{CH}_{2} \mathrm{O}-\right)$ groups, and where $x=3-5$ possess liquid properties similar to diesel.

\section{REFERENCES}

Abbasi, T., and Abbasi, S. A. (2011). 'Renewable' Hydrogen: Prospects and Challenges. Renew. Sustain. Energ. Rev. 15, 3034-3040. doi:10.1016/j.rser. 2011.02.026

Abu-Jrai, A., Tsolakis, A., Theinnoi, K., Cracknell, R., Megaritis, A., Wyszynski, M. L., et al. (2006). Effect of Gas-To-Liquid Diesel Fuels on Combustion Characteristics, Engine Emissions, and Exhaust Gas Fuel Reforming. Comparative Study. Energy Fuels 20, 2377-2384. doi:10.1021/ef060332a

Aepli, L., Frankiewics, T., and Meyer, E. (2020). An Overview of Renewable Natural Gas from Biogas. Washington DC, USA: US Environmental Protection Agency, Landfill Methane Outreach Program.

Aguayo, A. T., Ereña, J., Mier, D., Arandes, J. M., Olazar, M., and Bilbao, J. (2007). Kinetic Modeling of Dimethyl Ether Synthesis in a Single Step on a $\mathrm{CuO}-\mathrm{ZnO}-\mathrm{Al} 2 \mathrm{O} 3 / \gamma$-Al2O3 Catalyst. Ind. Eng. Chem. Res. 46, 5522-5530. doi: $10.1021 /$ ie 070269 s
DME can be produced from carbon dioxide and other carboncontaining waste materials. However, it also needs additional resources such as electricity, water and ultimately hydrogen, which must be sustainably obtained. Strategies to produce hydrogen from low-carbon energy sources were therefore reviewed. The processes that facilitate DME from waste feedstocks have been presented and the routes considered over the complete system. DME and OMEx production and properties have been put into a synthetic fuel context through comparison to the production of Fisher-Tropsch synthetic diesel. The ether route represents a low hydrogen and so lower overall energy route to a useful synthetic fuel. While we do not consider the use of DME as a silver bullet in a transport energy transition, we do not consider that any single solution technology will provide the answer. The clue lies in the word transition. We need to move away from fossil fuels in a way that is sustainable environmentally, financially, and socially. Whatever technology or suite of technologies are used, this needs to be introduced sensitively and must avoid creating transport fuel poverty where members of society are denied mobility as a consequence of a fuel ideology. This review demonstrates that in spite of the need for further innovation and development, DME has an important role to play in this transition as an energy vector, with the availability to store surplus or curtailed renewable energy over seasons.

\section{AUTHOR CONTRIBUTIONS}

Each author contributed to the literature review and analysis and to the writing of the paper. IOT was a Master's student who led the data acquisition and analysis and produced the first draft of the manuscript. PS was the research supervisor and GRMD Postdoctoral Research Associate and project co-supervisor.

\section{FUNDING}

The work was funded as part of the UKRI-Engineering and Physical Sciences (EPSRC) SUSTAIN Manufacturing Hub (EP/ S018107/1) and CO2Chem Network (EP/P026435/1) projects.

Ahmad, K., and Upadhyayula, S. (2018). Greenhouse Gas CO2 Hydrogenation to Fuels: A Thermodynamic Analysis. Environ. Prog. Sustain. Energ. 38, 98-111. doi:10.1002/ep.13028

Ainalis, D. T., Thorne, C., and Cebon, D. (2020). Technical Report White Paper: Decarbonising the UK's Long-Haul Rod Freight at Minimum Economic Cost, Centre for Sustainable Road Freight. Available at: http://www.csrf.ac.uk/wpcontent/uploads/2020/07./SRF-WP-UKEMS-v2.pdf.

Al-Mamoori, A., Krishnamurthy, A., Rownaghi, A. A., and Rezaei, F. (2017). Carbon Capture and Utilization Update. Energy Technol. 5, 834-849. doi:10. 1002/ente.201600747

Ali, K. A., Abdullah, A. Z., and Mohamed, A. R. (2015). Recent Development in Catalytic Technologies for Methanol Synthesis from Renewable Sources: A Critical Review. Renew. Sustain. Energ. Rev. 44, 508-518. doi:10.1016/j.rser. 2015.01.010

Alleman, T., and McCormick, R. (2003). "Fischer-Tropsch Diesel Fuels - Properties and Exhaust Emissions: A Literature Review,”. Technical Paper 2003-01-0763 (SAE International). 
Álvarez, A., Bansode, A., Urakawa, A., Bavykina, A. V., Wezendonk, T. A., Makkee, M., et al. (2017). Challenges in the Greener Production of Formates/Formic Acid, Methanol, and DME by Heterogeneously Catalyzed CO2 Hydrogenation Processes. Chem. Rev. 117, 9804-9838. doi:10.1021/acs.chemrev.6b00816

Apostolaki-Isofidou, E., Codani, P., and Kempton, W. (2017). Measurement of Power Loss during Electric Vehicle Charging and Discharging. Energy 127, 730-742. doi:10.1016/j.energy.2017.03.015

Arcoumanis, C., Bae, C., Crookes, R., and Kinoshita, E. (2008). The Potential of Dimethyl Ether (DME) as an Alternative Fuel for Compression-Ignition Engines: A Review. Fuel 87, 1014-1030. doi:10.1016/j.fuel.2007.06.007

Armenta, M. A., Maytorena, V. M., Flores-Sánchez, L. A., Quintana, J. M., Valdez, R., and Olivas, A. (2020). Dimethyl Ether Production via Methanol Dehydration Using $\mathrm{Fe} 3 \mathrm{O} 4$ and $\mathrm{CuO}$ over $\gamma$ - $\chi$-Al2O3 Nanocatalysts. Fuel 280, 118545. doi:10.1016/j.fuel.2020.118545

Arregi, A., Amutio, M., Lopez, G., Bilbao, J., and Olazar, M. (2018). Evaluation of Thermochemical Routes for Hydrogen Production from Biomass: A Review. Energ. Convers. Manage. 165, 696-719. doi:10.1016/j.enconman.2018.03.089

Asthana, S., Samanta, C., Bhaumik, A., Banerjee, B., Voolapalli, R. K., and Saha, B. (2016). Direct Synthesis of Dimethyl Ether from Syngas over Cu-Based Catalysts: Enhanced Selectivity in the Presence of MgO. J. Catal. 334, 89-101. doi:10.1016/j.jcat.2015.10.020

Avogadro (2021). Avogadro: an Open-Source Molecular Builder and Visualization Tool. Version 1.2.0. http://avogadro.openmolecules.net/ (Accessed May 12, 2021).

Azizi, Z., Rezaeimanesh, M., Tohidian, T., and Rahimpour, M. R. (2014). Dimethyl Ether: A Review of Technologies and Production Challenges. Chem. Eng. Process. Process Intensification 82, 150-172. doi:10.1016/j.cep.2014.06.007

Badwal, S., Giddey, S., Munnings, C., Bhatt, A., and Hollenkamp, A. (2014). Emerging Electrochemical Energy Conversion and Storage Technologies. Front. Chem. 2 (79), 1-28. doi:10.3389/fchem.2014.00079

Baranowski, C. J., Bahmanpour, A. M., and Kröcher, O. (2017). Catalytic Synthesis of Polyoxymethylene Dimethyl Ethers (OME): A Review. Appl. Catal. B: Environ. 217, 407-420. doi:10.1016/j.apcatb.2017.06.007

Baykara, S. (2004). Experimental Solar Water Thermolysis. Int. J. Hydrogen Energ. 29, 1459-1469. doi:10.1016/j.ijhydene.2004.02.011

Becker, W. L., Braun, R. J., Penev, M., and Melaina, M. (2012). Production of Fischer-Tropsch Liquid Fuels from High Temperature Solid Oxide Coelectrolysis Units. Energy 47 (1), 99-115. doi:10.1016/j.energy.2012.08.047

Benemann, J. R. (2000). Hydrogen Production by Microalgae. J. Appl. Phycol. 12, 291-300. doi:10.1023/a:1008175112704

Bhandari, R., Trudewind, C. A., and Zapp, P. (2014). Life Cycle Assessment of Hydrogen Production via Electrolysis - a Review. J. Clean. Prod. 85, 151-163. doi:10.1016/j.jclepro.2013.07.048

Bičáková, O., and Straka, P. (2012). Production of Hydrogen from Renewable Resources and its Effectiveness. Int. J. Hydrogen Energ. 37, 11563-11578. doi:10. 1016/j.ijhydene.2012.05.047

Bilke, M., Losch, P., Vozniuk, O., Bodach, A., and Schüth, F. (2019). Methane to Chloromethane by Mechanochemical Activation: A Selective Radical Pathway. J. Am. Chem. Soc. 141, 11212-11218. doi:10.1021/jacs.9b04413

Binder, M., Kraussler, M., Kuba, M., and Luisser, M. (2018). Hydrogen from Biomass Gasification. [online] IEA Bioenergy. Available at: https://www. ieabioenergy.com/wp-content/uploads/2019/01/Wasserstoffstudie_IEA-final.pdf (Accessed May 12, 2021).

Bonura, G., Cannilla, C., Frusteri, L., Catizzone, E., Todaro, S., Migliori, M., et al. (2020). Interaction Effects between $\mathrm{CuO}-\mathrm{ZnO}-\mathrm{ZrO} 2$ Methanol Phase and Zeolite Surface Affecting Stability of Hybrid Systems during One-step CO2 Hydrogenation to DME. Catal. Today 345, 175-182. doi:10.1016/j.cattod.2019.08.014

Borgert, K. J., and Rubin, E. S. (2017). Oxy-combustion Carbon Capture for Pulverized Coal in the Integrated Environmental Control Model. Energ. Proced. 114, 522-529. doi:10.1016/j.egypro.2017.03.1194

Brito Cruz, C. H., Souza, G. M., and Barbosa Cortez, L. A. (2014). "Biofuels for Transport," in Future Energy. Editor T. Letcher (Durban, South Africa: Elsevier), 215-244.

Burre, J., Bongartz, D., and Mitsos, A. (2019). Production of oxymethylene dimethyl ethers from hydrogen and carbon dioxide -part II: modeling and analysis for OME3 -5. Ind. Eng. Chem. Res. 58 (14), 5567-5578. doi:10.1021/acs. iecr.8b05577
Catizzone, E., Bonura, G., Migliori, M., Frusteri, F., and Giordano, G. (2017). CO2 Recycling to Dimethyl Ether: State-Of-The-Art and Perspectives. Molecules, [online] 23(1), p.31. Available at: https://www.mdpi.com/1420-3049/23/1/31/pdf-vor (Accessed May 12, 2021).

Catizzone, E., Freda, C., Braccio, G., Frusteri, F., and Bonura, G. (2021). Dimethyl Ether as Circular Hydrogen Carrier: Catalytic Aspects of Hydrogenation/ dehydrogenation Steps. J. Energ. Chem. 58, 55-77. doi:10.1016/j.jechem. 2020.09.040

Cave, E. (2020). Utilization of $\mathrm{CO}_{2}$ Emissions to Make Renewable Fuels and Chemicals SoCalGas Research Webinar. SoCalGas and Opus 12. Available at: www.gasworld.com/consortium-to-convert-co2-into-renewable-fuel/2019355. article (Accessed May 12, 2021).

Centi, G., and Perathoner, S. (2013). "Advances in Catalysts and Processes for Methanol Synthesis from $\mathrm{CO}_{2}$," in $\mathrm{CO}_{2}$ : A Valuable Source of Carbon. Green Energy and Technology. Editors M. Falco, G. Iaquaniello, and G. Centi (London: Springer), 147-169. doi:10.1007/978-1-4471-5119-7_9

Chaubey, R., Sahu, S., James, O. O., and Maity, S. (2013). A Review on Development of Industrial Processes and Emerging Techniques for Production of Hydrogen from Renewable and Sustainable Sources. Renew. Sustain. Energ. Rev. 23, 443-462. doi:10.1016/j.rser.2013.02.019

Chen, C.-Y., Liu, C.-H., Lo, Y.-C., and Chang, J.-S. (2011). Perspectives on Cultivation Strategies and Photobioreactor Designs for Photo-Fermentative Hydrogen Production. Bioresour. Technol. 102, 8484-8492. doi:10.1016/j. biortech.2011.05.082

Christopher, K., and Dimitrios, R. (2012). A Review on Exergy Comparison of Hydrogen Production Methods from Renewable Energy Sources. Energy Environ. Sci. 5, 6640-6651. doi:10.1039/C2EE01098D

Cuéllar-Franca, R. M., and Azapagic, A. (2015). Carbon Capture, Storage and Utilisation Technologies: A Critical Analysis and Comparison of Their Life Cycle Environmental Impacts. J. CO2 Utilization 9, 82-102. doi:10.1016/j.jcou. 2014.12.001

da Silva Veras, T., Mozer, T. S., da Costa Rubim Messeder dos Santos, D., and da Silva César, A. (2017). Hydrogen: Trends, Production and Characterization of the Main Process Worldwide. Int. J. Hydrogen Energ. 42, 2018-2033. doi:10. 1016/j.ijhydene.2016.08.219

Dang, C., Long, J., Li, H., Cai, W., and Yu, H. (2021). Pd-promoted Ni-Ca-Al Bifunctional Catalyst for Integrated Sorption-Enhanced Steam Reforming of Glycerol and Methane Reforming of Carbonate. Chem. Eng. Sci. 230, 116226. doi:10.1016/j.ces.2020.116226

De Simio, L., Gambino, M., and Iannaccone, S. (2013). Possible Transport Energy Sources for the Future. Transport Policy 27, 1-10. doi:10.1016/j.tranpol.2013. 01.006

Deutsch, D., Oestreich, D., Lautenschütz, L., Haltenort, P., Arnold, U., and Sauer, J. (2017). High Purity Oligomeric Oxymethylene Ethers as Diesel Fuels. Chem. Ingenieur Technik 89 (4), 486-489. doi:10.1002/cite. 201600158

Deutz, S., Bongartz, D., Heuser, B., Kätelhön, A., Schulze Langenhorst, L., Omari, A., et al. (2018). Cleaner Production of Cleaner Fuels: Wind-To-Wheel Environmental Assessment of CO2-based Oxymethylene Ether as a Drop-In Fuel. Energ. Environ. Sci. 11, 331-343. doi:10.1039/C7EE01657C

Dimitriou, P., and Javaid, R. (2020). A Review of Ammonia as a Compression Ignition Engine Fuel. Int. J. Hydrogen Energ. 45 (11), 7098-7118. doi:10.1016/j. ijhydene.2019.12.209

Dincer, I., and Acar, C. (2015). Review and Evaluation of Hydrogen Production Methods for Better Sustainability. Int. J. Hydrogen Energ. 40, 11094-11111. doi:10.1016/j.ijhydene.2014.12.035

Dincer, I., and Safari, F. (2020). A Review and Comparative Evaluation of Thermochemical Water Splitting Cycles for Hydrogen Production,. Energ. Convers. Manage. 205, 112182. doi:10.1016/j.enconman.2019.112182

Ecofys (2017). Assessing the Potential of $\mathrm{CO}_{2}$ Utilisation in the UK. [online] Ecofys 2017 by order of: UK Department for Business, Energy \& Industrial Strategy (BEIS). Available at: https://assets.publishing.service.gov.uk/government/uploads/system/ uploads/attachment_data/file/799293/SISUK17099AssessingCO2_utilisationUK_ ReportFinal_260517v2_1_.pdf (Accessed January 31, 2021).

Eroglu, E., and Melis, A. (2011). Photobiological Hydrogen Production: Recent Advances and State of the Art. Bioresour. Technol. 102, 8403-8413. doi:10.1016/ j.biortech.2011.03.026 
ETIP PVEuropean Photovoltaic Technology and Innovation Platform (2020). PHOTOVOLTAIC SOLAR ENERGY: BIG and beyond, Sustainable Energy to Limit Global Warming to 1.5 Degrees. [online] Available at: https://www.buildup. eu/sites/default/files/content/photovoltaic-solar-energy-big-and-beyond.pdf (Accessed January 5, 2021).

European Council directive 443/2009. Regulation (EC) No 443/2009 of 23 April 2009, Setting Emissions Performance Standards for New Passenger Cars, L 140/1-15

Fang, H. H. P., and Liu, H. (2002). Effect of pH on Hydrogen Production from Glucose by a Mixed Culture. Bioresour. Technol. 82 (1), 87-93. doi:10.1016/ s0960-8524(01)00110-9

Fiorese, G., Catenacci, M., Bosetti, V., and Verdolini, E. (2014). The Power of Biomass: Experts Disclose the Potential for success of Bioenergy Technologies. Energy Policy 65, 94-114. doi:10.1016/j.enpol.2013.10.015

Forrest, K., Mac Kinnon, M., Tarroja, B., and Samuelsen, S. (2020). Estimating the Technical Feasibility of Fuel Cell and Battery Electric Vehicles for the Medium and Heavy Duty Sectors in California. Appl. Energ. 276, 115439. doi:10.1016/j. apenergy.2020.115439

FreedomCAR and Fuel Partnership (2009). Hydrogen Production - Overview of Technology Options. [online] Available at: https://wwwl.eere.energy.gov/ hydrogenandfuelcells/pdfs/h2_tech_roadmap.pdf (Accessed January 18, 2021).

Galanova, E. G., Magomedova, M. V., Afokin, M. I., Starozhitskaya, A. V., and Maximov, A. L. (2021). Synthesis of Olefins from Dimethyl Ether in a Synthesis Gas Atmosphere. Catal. Commun. 153, 106297. doi:10.1016/j.catcom.2021. 106297

Gandia, L., Arzamedi, G., Dieguez, P., and Luis, M. G. (2013). Renewable Hydrogen Technologies. Pamplona, Spain: Elsevier Science \& Technology.

Gao, N., Cheng, M., Quan, C., and Zheng, Y. (2020a). Syngas Production via Combined Dry and Steam Reforming of Methane over Ni-Ce/ZSM-5 Catalyst. Fuel 273, 11770. doi:10.1016/j.fuel.2020.117702

Gao, W., Liang, S., Wang, R., Jiang, Q., Zhang, Y., Zheng, Q., et al. (2020b). Industrial Carbon Dioxide Capture and Utilization: State of the Art and Future Challenges. Chem. Soc. Rev. 49, 8584-8686. doi:10.1039/D0CS00025F

Ghavam, S., Taylor, C. M., and Styring, P. (2021). Modeling and Simulation of a Novel Sustainable Ammonia Production Process from Food Waste and Brown Water. Front. Energy Res. 9, 600071. doi:10.3389/fenrg.2021.600071

Gill, S. S., Tsolakis, A., Dearn, K. D., and Rodríguez-Fernández, J. (2011). Combustion Characteristics and Emissions of Fischer-Tropsch Diesel Fuels in IC Engines. Prog. Energ. Combustion Sci. 37, 503-523. doi:10.1016/j.pecs. 2010.09.001

Global Alliance Powerfuels (2020). Carbon Sources for Powerfuels Production. Berlin, Germany.

Global Carbon Capture and Storage Institute (2012). Pre Combustion Capture. $\mathrm{CO}_{2}$ Capture Technologies. [online] Palo Alto. Available at: https://www. globalccsinstitute.com/archive/hub/publications/29756/co2-capture-technologiespre-combustion-capture.pdf.

Goeppert, A., Czaun, M., Jones, J.-P., Surya Prakash, G. K., and Olah, G. A. (2014). Recycling of Carbon Dioxide to Methanol and Derived Products - Closing the Loop. Chem. Soc. Rev. 43 (23), 7995-8048. doi:10.1039/c4cs00122b10.1039/ c4cs00122b

Hallenbeck, P., and Benemann, J. R. (2002). Biological Hydrogen Production; Fundamentals and Limiting Processes. Int. J. Hydrogen Energ. 27, 1185-1193. doi:10.1016/S0360-3199(02)00131-3

Hänggi, S., Elbert, P., Bütler, T., Cabalzar, U., Teske, S., Bach, C., et al. (2019). A Review of Synthetic Fuels for Passenger Vehicles. Energ. Rep. 5, 555-569. doi:10. 1016/j.egyr.2019.04.007

Härtl, M., Gaukel, K., Pélerin, D., and Wachtmeister, G. (2017). Oxymethylene Ether as Potentially CO2-neutral Fuel for Clean Diesel Engines Part 1: Engine Testing. MTZ Worldw 78 (2), 52-59. doi:10.1007/s38313-016-0163-6

Henstra, A. M., Sipma, J., Rinzema, A., and Stams, A. J. (2007). Microbiology of Synthesis Gas Fermentation for Biofuel Production. Curr. Opin. Biotechnol. 18, 200-206. doi:10.1016/j.copbio.2007.03.008

Holladay, J. D., Hu, J., King, D. L., and Wang, Y. (2009). An Overview of Hydrogen Production Technologies. Catal. Today 139, 244-260. doi:10.1016/j.cattod. 2008.08.039

IDA Fact Sheet No. 2 (2010). International DME Association. Available at: www. aboutdme.org/aboutdme/files/ccLibraryFiles/Filename/000000001520/IDA_ Fact_Sheet_2_Transportation_Fuel.pdf (Accessed May 12, 2021).
IEA (2020a). CO2 Emissions from Fuel Combustion: Overview, IEA, Paris. Available at: https://www.iea.org/reports/co2-emissions-from-fuelcombustion-overview (Accessed April 11, 2021).

IEA (2019). The Future of Rail, IEA, Paris. Available at: https://www.iea.org/ reports/the-future-of-rail (Accessed April 11, 2021).

IEA (2020b). Transport Biofuels. [online] Paris: IEA. Available at: https://www.iea. org/reports/transport-biofuels (Accessed March 24, 2021).

INERIS (2020). Socio-economic Analysis of Biomass Based DME Production and Use. [online] Verneuil-en-Halatte: L'Institut National de l'Environnement Industriel et des Risques. Available at: http://www.fledged.eu/wp-content/ uploads/Downloads/Presentations/FinalWebinar/A6_FLEDGED\%20webinar \%20-\%20Shucht\%20-\%20Socio\%20economic\%20assessment.pdf (Accessed March 25, 2021).

IOGP (2019). The Potential for CCS and CCU in Europe. REPORT to the THIRTY SECOND MEETING of the EUROPEAN GAS REGULATORY FORUM 5-6 JUNE 2019. [online] Available at: https:/ec.europa.eu/info/sites/info/files/ iogp_-_report_-_ccs_ccu.pdf (Accessed January 31, 2021).

IRENA (2019). HYDROGEN: A RENEWABLE ENERGY PERSPECTIVE. Report Prepared for the 2nd Hydrogen Energy Ministerial Meeting. [online] Tokyo: The International Renewable Energy Agency (IRENA). Available at: https:// www.irena.org/-/media/Files/IRENA/Agency/Publication/2019/Sep/IRENA_ Hydrogen_2019.pdf (Accessed March 24, 2021).

Iribarren, D., Susmozas, A., Petrakopoulou, F., and Dufour, J. (2014). Environmental and Exergetic Evaluation of Hydrogen Production via Lignocellulosic Biomass Gasification. J. Clean. Prod. 69, 165-175. doi:10. 1016/j.jclepro.2014.01.068

Jansen, D., Gazzani, M., Manzolini, G., Dijk, E. v., and Carbo, M. (2015). Precombustion CO2 Capture. Int. J. Greenhouse Gas Control. 40, 167-187. doi:10. 1016/j.ijggc.2015.05.028

Johnson, B. (2020). Boris Johnson: Now Is the Time to Plan Our green Recovery. Financial Times. [online], 17 November, Available at: https://www.ft.com/ content/6c112691-fa2f-491a-85b2-b03fc2e38a30 (Accessed January 4, 2021).

Joo, O.-S., Jung, K.-D., Moon, I., Rozovskii, A. Y., Lin, G. I., Han, S.-H., et al. (1999). Carbon Dioxide Hydrogenation to Form Methanol via a Reverse-Water-GasShift Reaction (The CAMERE Process). Ind. Eng. Chem. Res. 38, 1808-1812. doi:10.1021/ie9806848

Kajitani, S., Chen, Z., Konno, M., and Rhee, K. (1997). "Engine Performance and Exhaust Characteristics of Direct-Injection Diesel Engine Operated with DME,". Technical Paper 972973 (SAE International).

Kanniche, M., Gros-Bonnivard, R., Jaud, P., Valle-Marcos, J., Amann, J.-M., and Bouallou, C. (2010). Pre-combustion, post-combustion and Oxy-Combustion in thermal Power Plant for CO2 Capture. Appl. Therm. Eng. 30, 53-62. doi:10. 1016/j.applthermaleng.2009.05.005

Kätelhön, A., Meys, R., Deutz, S., Suh, S., and Bardow, A. (2019). Climate Change Mitigation Potential of Carbon Capture and Utilization in the Chemical Industry. Proc. Natl. Acad. Sci. USA 116, 11187-11194. doi:10.1073/pnas. 1821029116

Kayfeci, M., Keçebaş, A., and Bayat, M. (2019). "Hydrogen Production," in Solar Hydrogen Production (Naples, Italy: Academic Press), 45-83. doi:10.1016/ B978-0-12-814853-2.00003-5

Khirsariya, P., and Mewada, R. K. (2013). Single Step Oxidation of Methane to Methanol-Towards Better Understanding. Proced. Eng. 51, 409-415. doi:10. 1016/j.proeng.2013.01.057

Kim, D.-H., and Kim, M.-S. (2011). Hydrogenases for Biological Hydrogen Production. Bioresour. Technol. 102 (18), 8423-8431. doi:10.1016/j.biortech. 2011.02.113

Kim, R. S., and Surendranath, Y. (2019). Electrochemical Reoxidation Enables Continuous Methane-To-Methanol Catalysis with Aqueous Pt Salts. ACS Cent. Sci. 5, 1179-1186. doi:10.1021/acscentsci.9b00273

Koishybay, A., and Shantz, D. F. (2020). Water Is the Oxygen Source for Methanol Produced in Partial Oxidation of Methane in a Flow Reactor over Cu-SSZ-13. J. Am. Chem. Soc. 142 (28), 11962-11966. doi:10.1021/jacs.0c03283

Kopyscinski, J., Schildhauer, T. J., and Biollaz, S. M. A. (2010). Production of Synthetic Natural Gas (SNG) from Coal and Dry Biomass - A Technology Review from 1950 to 2009. Fuel 89, 1763-1783. doi:10.1016/j.fuel.2010.01.027

Kothari, R., Buddhi, D., and Sawhney, R. L. (2008). Comparison of Environmental and Economic Aspects of Various Hydrogen Production Methods. Renew. Sustain. Energ. Rev. 12, 553-563. doi:10.1016/j.rser.2006.07.012 
Kothari, R., Buddhi, D., and Sawhney, R. L. (2004). Sources and Technology for Hydrogen Production: a Review. Int. J. Glob. Energ. Issues 21, 154. doi:10.1504/ ijgei.2004.004707

Kovacs, K., Maroti, G., and Rakhely, G. (2006). A Novel Approach for Biohydrogen Production. Int. J. Hydrogen Energ. 31, 1460-1468. doi:10.1016/j.ijhydene.2006.06.011

Kuramochi, T., Ramírez, A., Turkenburg, W., and Faaij, A. (2012). Comparative Assessment of CO2 Capture Technologies for Carbon-Intensive Industrial Processes. Prog. Energ. Combustion Sci. 38, 87-112. doi:10.1016/j.pecs.2011. 05.001

Larsson, M., and Denbratt, I. (2007). "An Experimental Investigation of FischerTropsch Fuels in a Light-Duty Diesel Engine,”. Technical Paper Series, 2007-010030 (SAE International)

Lautenschütz, L., Oestreich, D., Seidenspinner, P., Arnold, U., Dinjus, E., and Sauer, J. (2016). Physico-chemical Properties and Fuel Characteristics of Oxymethylene Dialkyl Ethers. Fuel 173, 129-137. doi:10.1016/j.fuel.2016. 01.060

Leckel, D. (2009). Diesel Production from Fischer-Tropsch: The Past, the Present, and New Concepts. Energy Fuels 23, 2342-2358. doi:10.1021/ef900064c

Lede, J., Lapicque, F., Villermaux, J., Cales, B., Ounalli, A., Baumard, J., et al. (1982). Production of Hydrogen by Direct thermal Decomposition of Water: Preliminary Investigations. Int. J. Hydrogen Energ. 7, 939-950. doi:10.1016/ 0360-3199(82)90162-8

Lee, U., Han, J., Wang, M., Ward, J., Hicks, E., Goodwin, D., et al. (2016). Well-toWheels Emissions of Greenhouse Gases and Air Pollutants of Dimethyl Ether from Natural Gas and Renewable Feedstocks in Comparison with Petroleum Gasoline and Diesel in the United States and Europe. SAE Int. J. Fuels Lubr. 9, 546-557. doi:10.4271/2016-01-2209

Lepage, T., Kammoun, M., Schmetz, Q., and Richel, A. (2021). Biomass-tohydrogen: A Review of Main Routes Production, Processes Evaluation and Techno-Economical Assessment. Biomass and Bioenergy 144, 105920. doi:10. 1016/j.biombioe.2020.105920

Levin, D. (2004). Biohydrogen Production: Prospects and Limitations to Practical Application. Int. J. Hydrogen Energ. 29, 173-185. doi:10.1016/s0360-3199(03) 00094-6

Luo, X., Wang, J., Dooner, M., and Clarke, J. (2015). Overview of Current Development in Electrical Energy Storage Technologies and the Application Potential in Power System Operation. Appl. Energ. 137, 511-536. doi:10.1016/j. apenergy.2014.09.081

Markewitz, P., Kuckshinrichs, W., Leitner, W., Linssen, J., Zapp, P., Bongartz, R., et al. (2012). Worldwide Innovations in the Development of Carbon Capture Technologies and the Utilization of CO2. Energ. Environ. Sci. 5, 7281-7305. doi:10.1039/C2EE03403D

Martínez-Rodríguez, A., and Abánades, A. (2020). Comparative Analysis of Energy and Exergy Performance of Hydrogen Production Methods. Entropy 22, 1286. doi:10.3390/e22111286

McKone, T., Rice, D., Ginn, T., Levy, D. A., Syz, B. A., and Boudreaux, R. (2015). Dimethyl Ether Multimedia Evaluation Tier I, Report for the California Environmental Protection Agency Multimedia Working Group. Available at: https://www.arb.ca.gov/fuels/multimedia/meetings/DMETierIReport_Feb2015. pdf (Accessed May 12, 2021).

Mehrpooya, M., and Habibi, R. (2020). A Review on Hydrogen Production Thermochemical Water-Splitting Cycles. J. Clean. Prod. 275, 123836. doi:10. 1016/j.jclepro.2020.123836

Melis, A., Zhang, L., Forestier, M., Ghirardi, M. L., and Seibert, M. (2000). Sustained Photobiological Hydrogen Gas Production upon Reversible Inactivation of Oxygen Evolution in the Green AlgaChlamydomonas Reinhardtii. Plant Physiol. 122, 127-136. doi:10.1104/pp.122.1.127

Michaelides, E. E. (2020). Thermodynamics and Energy Usage of Electric Vehicles. Energ. Convers. Manage. 203, 112246. doi:10.1016/j.enconman. 2019.112246

Michailos, S., McCord, S., Sick, V., Stokes, G., and Styring, P. (2019). Dimethyl Ether Synthesis via Captured CO2 Hydrogenation within the Power to Liquids Concept: A Techno-Economic Assessment. Energ. Convers. Manage. 184, 262-276. doi:10.1016/j.enconman.2019.01.046

Migliori, M., Condello, A., Dalena, F., Catizzone, E., and Giordano, G. (2020). CuZnZr-Zeolite Hybrid Grains for DME Synthesis: New Evidence on the Role of Metal-Acidic Features on the Methanol Conversion Step. Catalysts 10, 671. doi:10.3390/catal10060671
Mintz, M., and Voss, P. (2020). Database of Renewable Natural Gas (RNG) Projects: 2020 Update, Argonne National Laboratory, October 2020. Figure Calculated from MMBtu Figure Using the Ratio $1 \mathrm{MMBtu}: 21.10 \mathrm{Kg}$ Natural Gas. Available at: www.anl.gov/es/reference/renewable-natural-gas-database (Accessed April 11, 2020).

Mollavali, M., Yaripour, F., Atashi, H., and Sahebdelfar, S. (2008). Intrinsic Kinetics Study of Dimethyl Ether Synthesis from Methanol on $\gamma$-Al2O3Catalysts. Ind. Eng. Chem. Res. 47, 3265-3273. doi:10.1021/ie800051h

Moulijn, J., Makkee, M., and Diepen, A. (2013). Chemical Process Technology. 2nd ed. Chichester: John Wiley \& Sons Ltd. Hoboken, NJ, USA.

Najera, M., Solunke, R., Gardner, T., and Veser, G. (2011). Carbon Capture and Utilization via Chemical Looping Dry Reforming. Chem. Eng. Res. Des. 89, 1533-1543. doi:10.1016/j.cherd.2010.12.017

Nikolaidis, P., and Poullikkas, A. (2017). A Comparative Overview of Hydrogen Production Processes. Renew. Sustain. Energ. Rev. 67, 597-611. doi:10.1016/j. rser.2016.09.044

North, M., and Styring, P. (2019b). Carbon Dioxide Utilisation Volume 2: Transformations. Berlin; Boston: De Gruyter.

North, M., and Styring, P. (2019a). Carbon Dioxide Utilisation: Fundamentals. Berlin: Berlin/Boston De Gruyter.

Nwaoha, C., Supap, T., Idem, R., Saiwan, C., Tontiwachwuthikul, P., AL-Marri, M. J., et al. (2017). Advancement and New Perspectives of Using Formulated Reactive Amine Blends for post-combustion Carbon Dioxide (CO2) Capture Technologies. Petroleum 3, 10-36. doi:10.1016/j.petlm.2016.11.002

Oestreich, D., Lautenschütz, L., Arnold, U., and Sauer, J. (2018). Production of Oxymethylene Dimethyl Ether (OME)-hydrocarbon Fuel Blends in a One-step Synthesis/extraction Procedure. Fuel 214, 39-44. doi:10.1016/j.fuel.2017.10.116

Oh, Y.-K., Hwang, K.-R., Kim, C., Kim, J. R., and Lee, J.-S. (2018). Recent Developments and Key Barriers to Advanced Biofuels: A Short Review. Bioresour. Technol. 257, 320-333. doi:10.1016/j.biortech.2018.02.089

O’Mahoney, A. (2020). Ofgem Letter to Stakeholders on Revised Typical Domestic Consumption Values for Gas and Electricity and Economy 7 Consumption Split, UK Government. Available at: https://www.ofgem.gov.uk/system/files/ docs/2020/01/tdcvs_2020_decision_letter_0.pdf (Accessed April 11, 2021).

Oscar, P. R. van. Vliet., André, P. C. F, and Wim, C. T. (2009). Fischer-Tropsch Diesel Production in a Well-To-Wheel Perspective: A Carbon, Energy Flow and Cost Analysis. Energ. Convers. Manage. 50, 855-876. doi:10.1016/j.enconman. 2009.01.008

Ouda, M., Mantei, F. K., Elmehlawy, M., White, R. J., Klein, H., and Fateen, S.-E. K. (2018). Describing Oxymethylene Ether Synthesis Based on the Application of Non-stoichiomsetric Gibbs Minimisation. React. Chem. Eng. 3, 277-292. doi:10.1039/C8RE00006A

Ouda, M., Yarce, G., White, R. J., Hadrich, M., Himmel, D., Schaadt, A., et al. (2017). Poly(oxymethylene) Dimethyl Ether Synthesis - a Combined Chemical Equilibrium Investigation towards an Increasingly Efficient and Potentially Sustainable Synthetic Route. React. Chem. Eng. 2, 50-59. doi:10.1039/ C6RE00145A

Our World in Data (2020). Cars, Planes, Trains: Where Do CO2 Emissions from Transport Come from?. [online] Available at: https://ourworldindata.org/co2emissions-from-transport (Accessed January 2, 2021).

Parker, B. F., Zhang, Z., Rao, L., and Arnold, J. (2018). An Overview and Recent Progress in the Chemistry of Uranium Extraction from Seawater. Dalton Trans. 47, 639-644. doi:10.1039/C7DT04058J

Patel, H. A., Byun, J., and Yavuz, C. T. (2017). Carbon Dioxide Capture Adsorbents: Chemistry and Methods. ChemSusChem 10 (7), 1303-1317. doi:10.1002/cssc.201601545

Pélerin, D., Gaukel, K., Härtl, M., and Wachtmeister, G. (2020). "Nitrogen Oxide Reduction Potentials Using Dimethyl Ether and Oxymethylene Ether in a Heavy-Duty Diesel Engine,”. Technical Paper 2020-01-5084 (SAE).

Popov, B. N., Lee, J.-W., and Djukic, M. B. (2018). "Hydrogen Permeation and Hydrogen-Induced Cracking," in Handbook of Environmental Degradation of Materials. Editor M. Kutz. Third Edition (William Andrew Publishing), 133-162.

Porter, R. T. J., Fairweather, M., Kolster, C., Mac Dowell, N., Shah, N., and Woolley, R. M. (2017). Cost and Performance of Some Carbon Capture Technology Options for Producing Different Quality CO 2 Product Streams. Int. J. Greenhouse Gas Control. 57, 185-195. doi:10.1016/j. ijggc.2016.11.020 
Prasad, S., and Ingle, A. P. (2019). Sustainable Bioenergy. London, UK: Elsevier, 327-346.Impacts of Sustainable Biofuels Production from Biomass

Prince, R. C., and Kheshgi, H. S. (2005). The Photobiological Production of Hydrogen: Potential Efficiency and Effectiveness as a Renewable Fuel. Crit. Rev. Microbiol. 31, 19-31. doi:10.1080/10408410590912961

Qin, Z.-z., Su, T.-m., Ji, H.-b., Jiang, Y.-x., Liu, R.-w., and Chen, J.-h. (2015). Experimental and Theoretical Study of the Intrinsic Kinetics for Dimethyl Ether Synthesis from CO2over Cu-Fe-Zr/HZSM-5. Aiche J. 61, 1613-1627. doi:10. 1002/aic.14743

Ren, S., Fan, X., Shang, Z., Shoemaker, W. R., Ma, L., Wu, T., et al. (2020). Enhanced Catalytic Performance of $\mathrm{Zr}$ Modified $\mathrm{CuO} / \mathrm{ZnO} / \mathrm{Al} 2 \mathrm{O} 3$ Catalyst for Methanol and DME Synthesis via CO2 Hydrogenation. J. CO2 Utilization 36, 82-95. doi:10.1016/j.jcou.2019.11.013

Ren, S., Li, S., Klinghoffer, N., Yu, M., and Liang, X. (2019). Effects of Mixing Methods of Bifunctional Catalysts on Catalyst Stability of DME Synthesis via CO2 Hydrogenation. Carbon Resour. Convers. 2, 85-94. doi:10.1016/j.crcon. 2019.03.002

Rodríguez-Fernández, J., Ramos, A., Sánchez-Valdepeñas, J., and Serrano, J. (2019). Lubricity of Paraffinic Fuels Additivated with Conventional and Non-conventional Methyl Esters. Adv. Mech. Eng. 11, 1-8. doi:10.1177/ 1687814019877077

Roger, I., Shipman, M., and Symes, M. (2017). Earth-abundant Catalysts for Electrochemical and Photoelectrochemical Water Splitting. Nat. Rev. Chem. 1, 1-13. doi:10.1038/s41570-016-000310.1038/s41570-016-0003

Rounce, P., Tsolakis, A., Rodríguez-Fernández, J., York, A., Cracknell, R., and Clark, R. (2009). Diesel Engine Performance and Emissions when First Generation Meets Next Generation Biodiesel. SAE Tech. Paper Ser. doi:10. 4271/2009-01-1935

Royal Society (2019). Sustainable Synthetic Carbon Based Fuels for Transport, Policy Briefing Document. Available at: https://royalsociety.org/topics-policy/ projects/low-carbon-energy-programme/sustainable-synthetic-carbon-basedfuels-for-transport/ (Accessed 02 01, 21).

Sabatier, P., and Senderens, J. B. (1902). Nouvelles syntheses du methane. Comptes Rendus des Séancés de l'Académie des Science, 514-516.

Saleth, R., and Dinar, A. (2004). in The Institutional Economics of Water. Editor E. Elgar (Washington, DC, USA: World Bank and Cheltenham).

Sanna, A. (2013). Advanced Biofuels from Thermochemical Processing of Sustainable Biomass in Europe. Bioenerg. Res. 7, 36-47. doi:10.1007/s12155013-9378-4

Sansaniwal, S. K., Rosen, M. A., and Tyagi, S. K. (2017). Global Challenges in the Sustainable Development of Biomass Gasification: An Overview. Renew. Sustain. Energ. Rev. 80, 23-43. doi:10.1016/j.rser.2017.05.215

Semelsberger, T. A., Borup, R. L., and Greene, H. L. (2006). Dimethyl Ether (DME) as an Alternative Fuel. J. Power Sourc. 156, 497-511. doi:10.1016/j.jpowsour. 2005.05.082

Shah, V., Cheng, Z., Baser, D. S., Fan, J. A., and Fan, L.-S. (2021). Highly Selective Production of Syngas from Chemical Looping Reforming of Methane with $\mathrm{CO}_{2}$ Utilization on MgO-Supported Calcium Ferrite Redox Materials. Appl. Energ. 282, 116111. doi:10.1016/j.apenergy.2020.116111

Shen, W.-J., Jun, K.-W., Choi, H.-S., and Lee, K.-W. (2000). Thermodynamic Investigation of Methanol and Dimethyl Ether Synthesis from $\mathrm{CO} 2$ Hydrogenation. Korean J. Chem. Eng. 17, 210-216. doi:10.1007/BF02707145

Shi, L., Rossi, R., Son, M., Hall, D. M., Hickner, M. A., Gorski, C. A., et al. (2020). Using Reverse Osmosis Membranes to Control Ion Transport during Water Electrolysis. Energ. Environ. Sci. 13 (9), 3138-3148. doi:10.1039/D0EE02173C

Shi, Y., Liu, S., Liu, Y., Huang, W., Guan, G., and Zuo, Z. (2018). Quasicatalytic and Catalytic Selective Oxidation of Methane to Methanol over Solid Materials: a Review on the Roles of Water. Cataly. Rev. 62, 313-345. doi:10.1080/01614940. 2019.1674475

Shiva Kumar, S., and Himabindu, V. (2019). Hydrogen Production by PEM Water Electrolysis - A Review. Mater. Sci. Energ. Tech. 2, 442-454. doi:10.1016/j.mset. 2019.03.002

Show, K.-Y., Lee, D.-J., and Chang, J.-S. (2011). Bioreactor and Process Design for Biohydrogen Production. Bioresour. Technol. 102 (18), 8524-8533. doi:10.1016/ j.biortech.2011.04.055

Sia Partners (2016). Electrified Road Freight Transport Evaluating the Possibilities of External Electric Power Systems for Road Transport. [online] Available at: https:// www.sia-partners.com/system/files/document_download/file/2020-06/7. insight_electrified_road_freight_transport.pdf (Accessed January 4, 2021).

Sidhu, S., Graham, J., and Striebich, R. (2001). Semi-volatile and Particulate Emissions from the Combustion of Alternative Diesel Fuels. Chemosphere 42 (5-7), 681-690. doi:10.1016/s0045-6535(00)00242-3

Soares, J. F., Confortin, T. C., Todero, I., Mayer, F. D., and Mazutti, M. A. (2020). Dark Fermentative Biohydrogen Production from Lignocellulosic Biomass: Technological Challenges and Future Prospects. Renew. Sustain. Energ. Rev. 117, 109484. doi:10.1016/j.rser.2019.109484

Stangeland, K., Li, H., and Yu, Z. (2018). Thermodynamic Analysis of Chemical and Phase Equilibria in CO2 Hydrogenation to Methanol, Dimethyl Ether, and Higher Alcohols. Ind. Eng. Chem. Res. 57, 4081-4094. doi:10.1021/acs.iecr.7b04866

Styring, P., and Dowson, G. R. M. (2021). Oxygenated Transport Fuels from Carbon Dioxide : Driving towards Net Zero. Johnson Matthey Technol. Rev. 65, 170-179. doi:10.1595/205651321X16063027322661

Styring, P., Jansen, D., De Coninick, H., Reith, H., and Armstrong, K. (2011). Carbon Capture and Utilisation in the green Economy: Using $\mathrm{CO} 2$ to Manufacture Fuel, Chemicals and Materials. [online] CO2Chem Media \& Publishing Limited, Sheffield, UK. ISBN: 978-0-9572588-1-5. Available at: http://co2chem.co.uk/wp-content/uploads/2012/06/CCU\%20in\%20the\%20green \%20economy\%20report.pdf (Accessed 04 05, 21).

Styring, P., Quadrelli, E., and Armstrong, K. (2014). Carbon Dioxide Utilisation, Elsevier. ISBN: 9780444627469/9780444627483 (eBook).

Sun, W., Wang, G., Li, S., Zhang, R., Yang, B., Yang, J., et al. (2017). Speciation and the Laminar Burning Velocities of Poly(oxymethylene) Dimethyl Ether 3 (POMDME3) Flames: An Experimental and Modeling Study. Proc. Combustion Inst. 36, 1269-1278. doi:10.1016/j.proci.2016.05.058

Takeishi, K., and Akaike, Y. (2016). Hydrogen Production by Dimethyl Ether Steam Reforming over Copper Alumina Catalysts Prepared Using the Sol-Gel Method. Appl. Catal. A: Gen. 510, 20-26. doi:10.1016/j.apcata.2015.09.027

Teng, H., McCandless, J., and Schneyer, J. (2001). "Thermochemical Characteristics of Dimethyl Ether - an Alternative Fuel for CompressionIgnition Engines,". Technical Paper 2001-01-0154 (SAE International).

Thema, M., Weidlich, T., Hörl, M., Bellack, A., Mörs, F., Hackl, F., et al. (2019). Biological CO2-Methanation: An Approach to Standardization. Energies 12 (9), 1670. doi: $10.3390 /$ en 12091670

Turner, J., Sverdrup, G., Mann, M. K., Maness, P.-C., Kroposki, B., Ghirardi, M., et al. (2008). Renewable Hydrogen Production. Int. J. Energ. Res. 32, 379-407. doi:10.1002/er.1372

Uchida, H., and Harada, M. R. (2019). "Application of Hydrogen by Use of Chemical Reactions of Hydrogen and Carbon Dioxide," in Science and Engineering of Hydrogen-Based Energy Technologies (London, UK: Elsevier), 279-289.

Ugwu, A., Zaabout, A., Tolchard, J. R., Dahl, P. I., and Amini, S. (2020). Gas Switching Reforming for Syngas Production with Iron-Based Oxygen CarrierThe Performance under Pressurized Conditions. Int. J. Hydrogen Energ. 45, 1267-1282. doi:10.1016/j.ijhydene.2019.03.191

UK Department for Business, Energy and Industrial Strategy (2020). UK Energy Statistics, 2019 \& Q4 2019. London, UK.

Unilever (2020). Carbon Rainbow. Available at: https://www.unilever.com/news/ press-releases/2020/unilever-to-invest-1-billion-to-eliminate-fossil-fuels-incleaning-products-by-2030.html (Accessed February 01, 2021).

United NationsFramework Convention on Climate Change (2015). "Adoption of the Paris Agreement," in 21st Conference of the Parties (Paris: United Nations).

US deperatment of energy (2021). Fuel Properties Comparison. Alternative Fuels Data Center. [online] Available at: https://afdc.energy.gov/files/u/publication/ fuel_comparison_chart.pdf (Accessed March 25, 2021).

Vakili, R., Setoodeh, P., Pourazadi, E., Iranshahi, D., and Rahimpour, M. R. (2011). Utilizing Differential Evolution (DE) Technique to Optimize Operating Conditions of an Integrated Thermally Coupled Direct DME Synthesis Reactor. Chem. Eng. J. 168, 321-332. doi:10.1016/j.cej.2011.01.032

Verbeek, R., and Van der Weide, J. (1997). "Global Assessment of Dimethyl-Ether: Comparison with Other Fuels. International Spring Fuels \& Lubricants Meeting, Dearborn, Michigan,". Technical Paper 971607 (SAE International).

Vogt, C., Monai, M., Kramer, G. J., and Weckhuysen, B. M. (2019). The Renaissance of the Sabatier Reaction and its Applications on Earth and in Space. Nat. Catal. 2, 188-197. doi:10.1038/s41929-019-0244-4 
von der Assen, N., and Bardow, A. (2014). Life Cycle Assessment of Polyols for Polyurethane Production Using CO2 as Feedstock: Insights from an Industrial Case Study. Green. Chem. 16 (6), 3272-3280. doi:10.1039/C4GC00513A

Wang, S., and Yu, J. (2021). A Comparative Life Cycle Assessment on LithiumIon Battery: Case Study on Electric Vehicle Battery in China Considering Battery Evolution. Waste Manag. Res. 39 (1), 156-164. doi:10.1177/ 0734242 X20966637

Wang, Z., Paulauskiene, T., Uebe, J., and Bucas, M. (2020). Characterization of Biomethanol-Biodiesel-Diesel Blends as Alternative Fuel for Marine Applications. J. Mar. Sci. Eng. 8 (9), 730. doi:10.3390/jmse8090730

Willems, W. (2018). "Sustainable Fuels for Future Mobility: The DME Opportunity for CI-Engines," in 8th International DME Conference, 10th-12th September, 2018 (Sacramento, CA, USA).

Willems, W., Pannwitz, M., Zubel, M., and Weber, J. (2020). Oxygenated Fuels in Compression Ignition Engines. MTZ Worldw 81 (3), 26-33. doi:10.1007/ s38313-019-0183-0

Williams, C. R., and Bees, M. A. (2013). Mechanistic Modeling of Sulfur-Deprived Photosynthesis and Hydrogen Production in Suspensions ofChlamydomonas Reinhardtii. Biotechnol. Bioeng. 111, 320-335. doi:10.1002/bit.25023

World-nuclear.org (2020). Nuclear Power in France | French Nuclear Energy World Nuclear Association. [online] Available at: https://www.world-nuclear. org/information-library/country-profiles/countries-a-f/france.aspx (Accessed January 5, 2021).

Worldwide Fuel Charter Committee (2019). The Worldwide Fuel Charters. [online] 51-61. Available at: https://www.acea.be/uploads/publications/ WWFC_19_gasoline_diesel.pdf (Accessed January 14, 2021).
Xu, H. F., Wang, K. X., Li, W. S., and Zhou, X. P. (2005). Dimethyl Ether Synthesis from Methane by Non Syngas Process. Catal. Lett. 100, 53-57. doi:10.1007/ s10562-004-3085-X

Yang, Y., Niu, S., Han, D., Liu, T., Wang, G., and Li, Y. (2017). Progress in Developing Metal Oxide Nanomaterials for Photoelectrochemical Water Splitting. Adv. Energ. Mater. 7, 1700555.

Zhang, S., Shen, Y., Wang, L., Chen, J., and Lu, Y. (2019). Phase Change Solvents for post-combustion CO2 Capture: Principle, Advances, and Challenges. Appl. Energ. 239, 876-897. doi:10.1016/j.apenergy.2019.01.242

Zhang, W. (2010). Automotive Fuels from Biomass via Gasification. Fuel Process Technol. 91, 866-876. doi:10.1016/j.fuproc.2009.07.010

Zimmermann, A. W., Wunderlich, J., Müller, L., Buchner, G. A., Marxen, A., Michailos, S., et al. (2020). Techno-Economic Assessment Guidelines for CO2 Utilization. Front. Energ. Res. 8, 5. doi:10.3389/fenrg.2020.00005

Conflict of Interest: The authors declare that the research was conducted in the absence of any commercial or financial relationships that could be construed as a potential conflict of interest.

Copyright (c) 2021 Styring, Dowson and Tozer. This is an open-access article distributed under the terms of the Creative Commons Attribution License (CC BY). The use, distribution or reproduction in other forums is permitted, provided the original author(s) and the copyright owner(s) are credited and that the original publication in this journal is cited, in accordance with accepted academic practice. No use, distribution or reproduction is permitted which does not comply with these terms. 